\title{
BONSAIS IN A WILD FOREST? A HISTORICAL INTERPRETATION OF THE LONGEVITY OF LARGE SPANISH FAMILY FIRMS *
}

\author{
PALOMA FERNÁNDEZ PÉREZ \\ Universitat de Barcelona ${ }^{\mathrm{a}}$ \\ NÚRIA PUIG RAPOSO \\ Universidad Complutense de Madrid ${ }^{\mathrm{b}}$
}

RESUMEN

En este artículo se presentan los primeros resultados de una investigación en curso sobre la longevidad de las grandes empresas familiares españolas. Su principal objetivo es proporcionar datos sólidos sobre un tema en el que abundan más las opiniones que las estadísticas científicas, así como identificar las claves de la supervivencia y competitividad de las cerca de 250 empresas en que se basa el estudio. Se concluye que esta realidad no es sólo el resultado de dos décadas de integración económica en Europa o de una buena dotación de recursos naturales, sino también de un largo período de aprendizaje y de la combinación de dos factores: la especialización en nichos de mercado que no fueron objeto de interés estratégico por parte del Estado, y la habilidad para consolidar redes personales de cooperación e influencia dentro y fuera del país.

* Received 07/18/2007. Accepted 11/13/2007.

a Departament d'Història i Institucions Econòmiques, Escola Universitària d'Estudis Empresarials, Universitat de Barcelona, Diagonal 696, 08034 Barcelona. E-mail address: palomafernandez@ub.edu. The author is a member of the Centre de Recerca Antoni de Capmany and acknowledges financial support from the Ministerio de Educación y Ciencia, Research Project SEJ2005-02788.

b Departamento de Historia Económica, Facultad de Ciencias Económicas y Empresariales, Universidad Complutense de Madrid, Campus de Somosaguas, 28223 Pozuelo de Alarcón, Madrid. E-mail address: nuriapuig@ccee.ucm.es. The autor acknowledges financial support from the Ministerio de Educación y Ciencia, Research Project MEC-SEJ2006-15151. 
Palabras clave: Empresa familiar, gran empresa, longevidad, competitividad

\begin{abstract}
This study presents the first results of an on-going study of longevity of large Spanish family firms. Its main objective is to provide solid data for a topic in which opinions are more abundant than scientific statistics, as well as to identify the keys to the survival and competitiveness of the almost 250 firms included in the study. It concludes that this reality is not just the result of two decades of integration in Europe or a fortunate endowment with some natural resources, but the outcome of a long learning process and the combination of two factors: specialization in market niches in which the state had no strategic interests and the creation of personal networks of cooperation and influence within and outside Spain.
\end{abstract}

Keywords: Family firm, large firm, longevity, competitiveness

JEL Classification: D10, J16, M20, N01, N80

\title{
1. INTRODUCTION
}

There is a wide diversity of definitions of what a family firm is, but most scientists agree that the determining feature is the ownership structure, in which people linked by kinship ties own the controlling voting shares or property ${ }^{1}$. The way kinship ties are defined varies depending on cultural factors and may include blood ties as well as spiritual ties. As regards the percentage of voting shares or property needed to control the firm, these also vary depending on the legal framework governing entrepreneurial activity in each territory. This has changed quite substantially in Spain, as in other European countries, in the last two centuries ${ }^{2}$. Some historians have pointed towards the early modern

1 Howorth, Rose and Hamilton (2006). The authors want to express their gratitude for comments and suggestions received from editors and referees to improve concepts and evidences. They are also indebted in this process with Mary B. Rose, Ellie Hamilton, Andrea Colli, Jari Ojala, Pablo Díaz Morlán, and Mark Casson.

2 Limited ownership was possible in Spain after the 1829 Code. Today the Spanish lobby of large family firms Instituto de la Empresa Familiar is working hard to modify the existing law, or even to create a new mercantile law to allow an increase in the percentage of shares without voting rights in limited companies in Spain. In this way family firms with high capi- 
times as the age of the first consolidation of family capitalism, linking it with the rise of the bourgeoisie as a social class. Well-known anthropologists, though, place the establishment of family-owned businesses in earlier times and in tribal societies ${ }^{3}$.

Economists and business historians have rarely considered family firms as efficient and flexible institutions able to learn from and also teach to lessons of competitiveness from big corporations. In contrast with big managerial corporations of some leading economies and sectors of the II Technological Revolution, family firms appear as losers in the race for competitiveness in contemporary business history ${ }^{4}$. However, in recent decades, interdisciplinary scholarship on family firms in Europe, the U.S.A. and Asia, has indicated that in the last 150 years many large and medium family firms have managed to learn and successfully use organizational skills from big corporations, and at the same time have been able to maintain family control and values ${ }^{5}$. Personal networking has proved a very efficient tool for building the channels of trust across regional and national borders so important in international businesses today ${ }^{6}$. Renewed studies of the economics of family firms are also revealing some very important competitive advantages of family firms in the manufacturing sectors which are very strategic skills in our globalization era: flexibility to adapt to changes and innovate, cost saving personal networking, and better skills to create intangible assets like reputation and brands ${ }^{7}$. The study of the geography and longevity of family firms in a country can, therefore, contribute important insights into the concentration and availability of human capital in a territory, which is one of the goals of this study.

Over centuries family firms have been the most common ownership structure across countries and sectors. Relying on a strong basis of trust, family firms offered the means to coordinate efforts and resources adequately and to face uncertainty ${ }^{8}$. Trust-based networks seemed to lose much of their pre-eminence in the most advanced parts of the world between the eighteenth-century and the end of the 1970s as a consequence of the spread of economic liberalism, the growth of productivity and the

tal requirements (needed to innovate and/or internationalize) could open their ownership to outsiders without losing key controlling rights, the sign of their autonomy and independence. See interview with Fernando Casado in Bibko (2002): 45.

${ }^{3}$ Classic historical approaches are Stone (1977) and Braudel (1982). For an excellent anthropological approach, see Goody (1983).

4 On the family firm debate see Jones and Rose (1993); Colli (2003); and Howorth, Rose, and Hamilton (2006: 225-247). On the comparison between some big US corporations and UK and German firms, see Chandler (1994).

5 James (2006), Casson and Godley (eds.) (2000), Colli (2003).

6 Castells [2000 (ed.), 2004 (ed.)], and Galambos (2005: 1-38).

7 Galve and Salas (2003).

${ }^{8}$ Granovetter (1995: 93-130). 
fall of transportation and communication costs linked to the industrialization process ${ }^{9}$. It was indeed in the regions and countries where the new sectors developed earlier and more intensely that the "Chandlerian» firm emerged. This happened firstly in the United States, Germany, the United Kingdom and France, and later in the European periphery and the Far East. As the II Technological Revolution progressed, regions and firms that remained rooted in the industrialized sectors of the I Technological Revolution were considered to be dominated by a backward-looking personal and family type of capitalism ${ }^{10}$.

This static view, so dominant for many years in debates about modern business structures, failed to see change and adaptation of the old family firm structures ${ }^{11}$. In many countries, some family firms started to change their inherited traditional features in a very slow and disperse way. It was such a slow transformation that it was difficult for researchers to identify the changes as a coherent trend across national borders and sectors. However, these scattered changes were in fact complementary pieces of a general learning process. In this process many large and medium family firms adapted their structures and organization to the impact of technological change and global demand in a way which resembled, but was at the same time different to, the path followed by the Chandlerian corporation ${ }^{12}$.

Large family firms in Europe, Asia and America learnt to professionalize their family management, to borrow from banks without losing family control, and many opened their ownership to the public stock market, particularly during the second half of the $20^{\text {th }}$ century. Those who benefited most from all these transformations increased their scale, scope and profits, and contributed to regional wealth.

Management literature indicates that long term family business groups incorporate four priorities which foster enduring success: command (senior independence), continuity (adherence to a mission), com-

\footnotetext{
9 Chandler, Amatori and Hikino (eds.) (1997).

${ }_{10}$ On a review of the family firm debate in Rose (1995).

11 Jones and Rose (eds.) (1993), Colli (2003). With diversified regional experiences, of course. For the UK outdoor trade, see Parsons and Rose (2003) and Parsons and Rose (2004). For various European countries and sectors, see Fernández Pérez and Rose (eds.) (forthcoming).

${ }_{12}$ As with the managerial corporations Chandler studied for the US between the mid $19^{\text {th }}$ century and the mid $20^{\text {th }}$ century, in some European family firms changes in technology and markets led to growth, diversification and vertical integration. However, and in contrast with the US firms, European family firms remained tightly controlled by people linked by kinship ties, who started processes of improvement of their technical and managerial training. On their productive and commercial changes see James (2006). On the professionalization of management, see Guillén (2004), Puig and Fernández (2003) and an article by these authors is forthcoming in Revista de Historia de la Economía (Fundación BBVA).
} 
munity (unity and concern for employees), and connection (long-lived external relationships with clients and suppliers) ${ }^{13}$. However, from a historical and new institutional economics point of view, which is the conceptual approach of this article, the explaining factors of business success and failure identified in a particular place or economic sector cannot be simply extrapolated to other places or times ${ }^{14}$. The interplay of family firms with their particular environment conditions their priorities to a great extent ${ }^{15}$.

This article represents a move towards an improved understanding of the dynamism shown by family capitalism in Europe during the golden age of the managerial corporation between the last third of the $19^{\text {th }}$ and $20^{\text {th }}$ centuries. In this period, European family firms learnt new strategies and structures which, mixed with preserved family firm competitive advantages, allowed survival and success. We approach this process through the study of the longevity and geographical distribution of the largest historical Spanish family firms. The Spanish evidence includes family firms which had operated for many decades under the umbrella of a highly interventionist and isolationist dictatorship. The obstacles and difficulties these family firms faced during the central years of the "golden age of capitalism» were thus probably more important than in other European countries, where state interventionism took place but not with the strong and enduring isolationist goals of the Spanish state, and therefore the efforts towards transformation and change of Spanish family firms were very different ${ }^{16}$.

The article presents original new data about the longevity of 245 large Spanish family firms and has two main goals. Firstly, to provide solid data about a topic in which opinions are more abundant than scientific statistics. Secondly, to demonstrate that the competitiveness of large Spanish family firms is not just the result of two decades of integration in Europe or a good endowment with some natural resources, as economic analysis without historical perspective indicates, but the outcome of a peculiar combination of two factors that have taken place in Spain over more than a century: specialization in market niches in which the state had no strategic interests or public firms (above all during Franco's dictatorship), and the creation of personal business networks within and outside the firms' regions.

Available economic studies in the field of Spanish family-controlled manufacturing firms at the end of the $20^{\text {th }}$ century have indicated their

\footnotetext{
13 Miller and Le Breton-Miller (2005: 6).

14 Jones and Rose (1993).

15 Colli, Fernández Pérez, Rose (2003).

16 On Spanish interventionism and isolationism see Catalan (1995, 2003).
} 
specialization in the consumer goods industries and in relatively low added value metal mechanical manufacturing, both sectors which are not very capital intensive ${ }^{17}$. Also, a few of these studies have carried out comparative work to contrast the performance of family owned firms in the Spanish manufacturing sector with that of non-family firms. According to these studies, large Spanish family firms were able to keep ownership control in the industrial sector in a more stable way than financial and public firms during the difficult years of industrial crisis and increased foreign competition of the $1980 \mathrm{~s}^{18}$. This happened despite the fact that, according to Galve and Salas, the numbers and percentages of all family-owned firms (large, medium and small) in the total number of Spanish manufacturing firms fell during the $1990 \mathrm{~s}^{19}$. This indicates, by the end of the $20^{\text {th }}$ century, high death rates of smaller and medium firms and a parallel process of concentration of small or inefficient firms around medium and large family firms, both developments for which we have scattered qualitative evidence that future research will have to measure and explain in a more comprehensive way. What is absolutely clear is the outcome of these processes of change and transformation over recent decades: half of the largest Spanish multinationals today are family-owned firms and the vast majority of the best-known Spanish brands on international markets are "family firm made» ${ }^{20}$.

This study will attempt to understand not so much this rapid transformation and the internationalization processes of large Spanish family firms during the last three decades, but rather the historical reasons behind the high number of large family firms in our country. Economic studies point towards some possible competitive advantages for contemporary manufacturing family firms such as flexibility to innovate, cost-saving strategies for networking in times of crisis and expansion, and commercial skills to create brands and reputation ${ }^{21}$. However, until now we have not had a historical overview of the long term reasons behind the dynamism of Spanish family capitalism. This article is a first quantitative contribution towards this effort.

\footnotetext{
17 Galve and Salas (2003): 85.

18 Between 1982-1992 the control of the 538 largest industrial manufacturing firms in Spain varied: in the public sector from 11,7 per cent to 10,5 per cent; financial capital controlled firms from 12,3 to 6,6 per cent; foreign capital firms from 32,5 to 48,7 per cent, and family controlled firms from 16,6 per cent to 16,8 per cent. In Nadal (dir.) (2003), p. 408 .

19 Galve and Salas (2003): 85.

20 On Spanish brands see Murray (2002): 52-53. On the internationalization of large Spanish family firms, Nuria Puig and Paloma Fernández presented first results in «Silent Revolution: The internationalization of large Spanish historical family firms», European Business History Conference, Geneva, September 2007 (publication forthcoming).

21 Galve and Salas (2003): 98-99, 117 and 190-191. They also indicate, however, high vulnerability to external shocks and difficulties obtaining capital from outsiders.
} 
We have created and used our own database of 245 firms and a multitude of scattered biographies and entrepreneurial monographs. The firms are family owned or managed, large (turnovers in excess of 40 million euros), and historical (having experienced at least one successful succession process by the end of 2005). The database has been compiled with information from Actualidad Económica 2006, corporate websites, published business articles and books, interviews with the Instituto de la Empresa Familiar (IEF) and with Spanish regional associations of family firms ${ }^{22}$. Despite the scattered nature of the evidence, these are the only available data gathered on medium and large historical Spanish family firms ${ }^{23}$.

According to our data, in 2005 there were 3,712 firms with a turnover in excess of 40 million euros in Spain. Turnover has been taken as the main criteria for selecting the largest Spanish family firms. Around 1,000 of them (25 per cent) are family owned or managed. Most of the firms are small by international standards. Half of these 1,000 largest Spanish family firms are located in Madrid (56 per cent), and only 16 per cent in Catalonia.

Because a study of longevity needs to take into account family firms that have successfully undergone at least one succession process we will call this group «historical family firms». The view radically changes when locating the largest historical family firms: 23 per cent of the total number of firms. 37.7 per cent of these firms are in Catalonia; 14.4 per cent in Madrid; 7.6 per cent in the Autonomous Community of Valencia; 6.9 per cent in Andalusia; 6,2 per cent in the Basque Country; and less than 5 per cent in the other Autonomous Communities of Spain (see Tables 1 and 2). This means that in 2005 the largest Spanish family firms of all ages were concentrated in Madrid, but large historical family firms were concentrated in the Mediterranean basin - particularly in Catalonia.

In the following sections we will offer a preliminary analysis of the identity, geography, specialization, and longevity of large historical family firms in Spain. This section will indicate where major competitive advantage is to be found among large family firms and will identify

${ }^{22}$ We particularly wish to thank Fernando Casado of the IEF, Jesús Casado in Madrid, and the efforts of the regional associations of the IEF which answered our questionnaire and, in cases like the Alicante and the Catalan associations, provided excellent information.

${ }^{23}$ These are the first results of on-going research, but they are so far the only scientific data gathered on longevity of Spanish family firms. Most analysis of Spanish family firms only offer estimates and percentages with no statistical support. Studies of Spanish family firms which use the firms' answers to public questionnaires available since the 1990s, like Galve and Salas (2003), are exceptions. These studies, however, include limited data on the longevity of firms. 
the older and younger firms and regional distribution and specialization. The questions will then be why and how the older large family firms have been able to become successful in a very competitive global market, despite traditional backwardness, isolation and two military dictatorships which imposed backward-looking business policies during five decades of the $20^{\text {th }}$ century. The next section will try to present some answers to these two questions from a historical perspective, in order to identify not only transformation and change, but also the factors leading to such change. We will see that the regional perspective is historically the most appropriate in order to understand the roots of the competitive advantage of these firms, as is the case in most of Europe. We will also use the available scattered evidence of published and unpublished studies to try to identify the most significant trends of the long learning process through which medium and large Spanish family firms were able to change their inward-looking approach to business for outward-looking competitive strategies. The final conclusion section will summarize the major findings, particularly the idea that this dynamism of some large family firms is not just the result of two decades of integration in Europe or a good endowment with some natural resources, as economic analysis without historical perspective may indicate, but also the outcome of a peculiar combination of two factors that has taken place in Spain over more than a century: specialization in market niches in which the state had no strategic interests or public firms, and the creation of personal business networks within and outside the firms' regions.

\section{LARGE FAMILY FIRMS IN $21^{\text {ST }}$ CENTURY SPAIN}

As previously observed, in 2005 the largest Spanish firms according to turnover were geographically concentrated in Madrid. However, the oldest among them were concentrated in Catalonia. The concentration in Madrid may reveal the economic and political attraction of the capital as well as the benefits derived from the reduction in inheritance taxes experienced in the Autonomous Region of Madrid in this decade ${ }^{24}$. In order to study longevity and thus the skills involved in changing and adapting to environmental shocks, we have selected firms which have reached at least the second generation («historical family firms») and have a turnover of more than 40 million euros. According to estimates from the Spanish IEF only 15 per cent of these firms had reached the

\footnotetext{
${ }^{24}$ This reduction has taken place in other Autonomous Communities such as Castile and Leon since 2000. This was a successful result of regional family firm lobbies according to representatives of the IEF. See Corona and Casado (2002: 40-41).
} 
third generation in Spain in $2002^{25}$. Table 1 shows the largest 245 firms which met the requirements explained above in 2005.

Our first observation is related with the geography of historical Spanish family firms. A significant 68 per cent (167 firms) of our sample have their headquarters in Catalonia, Madrid, Aragon, the Basque Country and Valencia. All these territories, with the exception of Madrid (whose localization advantages are strongly political or bureaucratic), have historically been industrial regions with a strong influence of one-heir traditions. Their branch of activity is, in most cases, related to the consumer goods industries, construction, services, and very specialized capital intensive market niches like pharmaceuticals and light metal industries. In Catalonia recent and large family firms are highly specialized in food and beverages, chemicals and pharmaceuticals and construction. In Madrid the historical family firm has a weaker industrial profile with retailing, construction and communication standing out. As for Valencia, the Basque Country and Aragon, these regions have rather industrial and diverse profiles. Food and beverages are by far the dominant activities of those firms located in Andalusia, Castile, Galicia, Murcia, Navarre and the Rioja region. In the Balearic Islands, the largest family firms grew up around the footwear industry and later focused on Spain's principal economic activity, tourism.

If we turn our attention to chronology in Catalonia, the number of firms founded before the end of the Spanish Civil War (1936-1939) is 33, more than a third of the total number of Catalan firms included in the table (84). It is important to note that many of them were established in the 1920s. Half of the Catalan firms were set up during Franco's dictatorship and they show a great diversity of economic activities in comparison with the other, much more specialized Spanish regions. In Madrid, the post-war regime encouraged the growth of groups linked to construction, distribution and communications ${ }^{26}$. However, the surviving firms have a rather heterogeneous profile. A different view is to be found in the Northern region of the Basque Country: the dismantling of traditional industries in the Basque Country has changed its entrepreneurial landscape in recent decades: accumulated capital and families persist, but many firms have disappeared. Table 1 suggests that historical family firms of medium and large size have grown in the shadow of the second industrial revolution.

25 See Bibko (2002),

${ }^{26}$ Many public firms located in Madrid were sold and private firms were able to take control, as happened in the car and metal industries. On INI and the privatization process see Nadal (dir.) (2003): 418-421. 
The other regions have diverse profiles, but with some key specialized historical niche branches. In Valencia, the labour-intensive industries that once characterized its entrepreneurial fabric are fading, in contrast with the rise of retailing, ceramics and construction. In Andalusia, the engineering firm Abengoa (whose Madrid offices are actually much larger than those in Seville) overshadows some of the most venerable and best known manufacturers of sherry and other alcoholic beverages. The chronology of Aragon's family firms is similar to that of Catalonia. In those regions with a strong agricultural profile, (Galicia, Castile, Navarre, Murcia, and Rioja) we observe a strong presence of agro industrial family firms linked to the canned food industries. It should be noted that winemaking, an important activity throughout Spain, is practically absent from our data because most wineries are usually small in both size and turnover. Banco de Santander is the only survivor in Cantabria, managed by the second and third generations of the Botín family. Finally, in the Balearic Islands, both pre-war and post-war firms have succeeded in adapting to the dramatic transformation of the local economy led by tourism. The development of the Canary Islands is quite different.

Although our study is preliminary, it shows that historical firms present a high degree of geographical concentration (and thus potential for collective action), and a relative specialization in diversified labour intensive and low productive activities (see Table 3). They also show that the specific endowment of natural resources and human capital in each region seems to have been of the utmost importance. Table 1 provides valuable data regarding the key chronological periods when the currently successful large Spanish family firms were founded. Table 2 summarizes this chronological information to identify the key fertile periods during which today's large, successful historical Spanish family firms came into being. Table 2 shows that from the total 245 family firms, 82 firms were set up before the end of the Spanish Civil War (1936-39), and 163 firms after the end of the war. Table 2 indicates four sub-periods indicating the economic cycles which helped or hindered the birth of these enduring family firms: 37 family firms were established before the $20^{\text {th }}$ century, 45 during the first third of the $20^{\text {th }}$ century, 126 during Franco's dictatorship and 37 after 1975. The information is clearly biased in favour of Catalonia, the region with most data. Of a total of 84 large Catalan family firms, 15 were set up before the $20^{\text {th }}$ century, 18 during the first third of the $20^{\text {th }}$ century, 43 during Franco's regime, and 8 after 1975.

The conclusion regarding chronology from Tables 1 and 2 is clear: the decades of Franco's dictatorship witnessed the foundation of half of the largest historical family firms active in Spain today. However, an ear- 
lier period, the first third of the $19^{\text {th }}$ century and the first two decades of the $20^{\text {th }}$ century, when more than a third of our firms were founded, was also a very fertile one for large, durable family firms. These data provide evidence to confirm our idea that today's successful Spanish family multinationals owe a good deal of their endurance to conditions linked not just to present-day strategies but to the accumulated inheritances of the past. The fact that these two particularly fertile periods for enduring family firms were rather protectionist and isolationist periods in Spain's economic history would suggest that, as has been the case in other industrialized economies of the world like the US, protection in a backward developing economy may help future growth and internationalization, at least for those firms able to combine this protective umbrella with internal organizational transformations. During the dictatorships of Primo de Rivera (1923-1929) and Franco (1939-1975), large industrial firms with the power to lobby the political authorities greatly benefited from laws which protected national industries and reserved the Spanish market for Spanish producers ${ }^{27}$. These firms were also able to grow because many of them were able to take advantage (later and with greater import difficulties than in other European economies) of the mass production/distribution techniques of the second industrial revolution ${ }^{28}$. They grew slowly compared with the Italian pocket multinationals of this period, due to great import difficulties, but many showed great dynamism on international markets before 1936 when they were forced by the autarky to grow in closer connection with their domestic market.

In Catalonia there were many examples of medium-sized family firms which internationalized between the late $19^{\text {th }}$ century and the early 1930s in specialized regionally-embedded market niches like papermaking, alcoholic beverages, food production, and cork or book manufacturing. Latin America and France were the preferred destinations of this Spanish foreign presence, and some even tried the U.S.A. market. For instance, Pau Miquel i Costas opened his first distribution establishment in La Habana in 1880, Rafael Guastavino moved to New York and established the renowned «Guastavino Fireproof Construction Company» in the 1880s, the Mateu family opened the first subsidiary of their car factory Hispano Suiza in France in 1912, the Jorba family established the significant retail store Maison Jorba in Brussels in 1919, the Salvat family of publishers spread their exports throughout Latin America in the first decade of the $20^{\text {th }}$ century, Daniel Carasso established the first French factory of the Catalan family firm Danone in

27 García Delgado (1999).

28 Nadal (2003). 
Lavallois Pret in 1932 and agreements with foreign partners to transfer modern technology were signed by the Vilà family of textile industrialists with French partners in 1923. Perfume manufacturers like Myrurgia of the Monegal family used to hire French technicians to update their designs and marketing techniques in the 1920s. The cork producer Joan Miquel i Avellí managed to transform his «Manufacturas de Corcho» (founded in 1916) into the European leader of cork manufacturing in 1929. Whereas some of these and similar firms disappeared after the war, many others were acquired along with their brands and know-how by surviving firms, and others like Miquel i Costas have endured as remarkable family firms able to adapt flexibly to new times ${ }^{29}$.

The individual stories of many of the firms included in our sample for the year 2005 show indeed that they have become global actors thanks to the efforts and experiences accumulated in the two favourable periods mentioned above. During the first third of the $20^{\text {th }}$ century some of today's European and multinational leaders in specialized branches of production had their roots in Spain: in the food industries Agrolimen and Calvo; in engineering and construction FCC and Acciona, in legal services Cuatrecasas, in tourism and travel Barceló and Iberostar, and in retail store distribution El Corte Inglés, to mention a few. Some of the most important large Spanish family firms appeared during the 1940s and, especially, during the 1950s: in engineering Ferrovial, Abengoa, Técnicas Reunidas, Talgo and Sener; in paper production SAICA; the Valencian ceramic and toy producers Lladró, Porcelanosa and Famosa; pork meat producer Campofrío, or mattress manufacturer Pikolin.

The next section focuses in more detail on some of the keys behind the historical process in which these firms took advantage of environmental and institutional factors, and how they survived the darkest times of autarky and backwardness. It was a long learning process in which knowledge transfer from abroad and good family team work played a crucial role, alongside a third important factor: specialization in market niches in which costs had been lower than in capital intensive firms, and in which public firms had no interest ${ }^{30}$.

${ }^{29}$ On Antoni Miquel i Costas see Gutiérrez (2006: 198). On Damià Mateu, Joan Jorba Rius, Pau Salvat i Espasa, Isaac Carasso, Joseph Vilà i Marqués, Joan Miquel i Avellí, and Esteve Monegal Prat see respectively studies by López Carrillo, Oliveras Samitier, Cabana, Aymerich, Moreno Castaño, Sala and Puig Raposo in Cabana (eds.) (2006: 264, 308, 331, 343-4, 349, 353 and 451).

30 See Pascual Domènech and Fernández Pérez (eds.) (2007). 


\section{A LONG LEARNING PROCESS OF SURVIVAL AND ADAPTATION}

\subsection{The $19^{\text {th }}$ and early $20^{\text {th }}$ century: a failed opportunity for some, time to grow for others}

Between the mid $18^{\text {th }}$ and early $20^{\text {th }}$ centuries, the Spanish Empire collapsed and Spain became merely a peripheral European nation ${ }^{31}$. Spain's industrialization started in a few outlying regions and under the aegis of an increasingly protectionist framework that focused on agriculture and a few industrial sectors.

The state, however, did little to support education and thereby to invest in human capital before the 1930s. It also failed to design a rational plan of infrastructures aimed at unifying the domestic market ${ }^{32}$. In contrast, the state was extremely lax in fiscal and labour matters, so that the costs of private enterprise were kept low and the labour market remained highly flexible in Spain until the first third of the $20^{\text {th }}$ century. In spite of the fact that the formation of human capital was not favoured, labour market flexibility helped to consolidate informal mechanisms of knowledge transfer between firms in industrial districts, as was happening in most of Europe, and this was the case in some Basque (metal industries), Valencian (the footwear industry) and Catalan (textile and metal industries) industrial districts during this century and during the good times of neutrality in the First World War ${ }^{33}$.

In the Catalan case, the modernization of the textile, food, metal, and chemical industries during the $19^{\text {th }}$ and early $20^{\text {th }}$ centuries was carried out to a large extent by a few prominent families. Bonaplata, Planas, Güell, López-Güell, Muntadas, Ferrer-Vidal, Serra-Bertrand, Batlló, Puig-Fabra, Marqués, Sedó, Rosés, Torras and Rivière, among others, can be mentioned ${ }^{34}$. Many of the firms that have survived and become large and international have their roots in precisely this region. This is the case of the wine makers Raventós-Codorniu, Ferrer-Freixenet, Torres, the pharmacists Uriach and Esteve, perfume manufacturer Puig, paper manufacturers Torras, publishers Godó and Salvat, metal manufacturers Roca, steel wire manufacturers Rivière (bought by Celsa in 1999), construction entrepreneurs Roviralta, and optical equipment manufacturers Cottet $^{35}$.

\footnotetext{
31 Prados de la Escosura (1991)

32 On education see Núñez and Tortella (eds.) (1993). On infrastructures see Gómez Mendoza (1982). (2003).

33 For several regions and sectors see Nadal and Catalan (eds.) (1994), and Nadal (dir.)

34 Cabana (ed.) (2006). Also Puig (2006).

35 Cabana (ed.) (2006).
} 
Roca, a world leading sanitary equipment manufacturer, is a case in point ${ }^{36}$. The small iron workshop of Ignasi Soler, established in Manlleu in 1830 , was transformed several times during the $19^{\text {th }}$ century to adapt first to steam power and to provide auxiliary services to the textile industry and house appliances demand, and later, at the end of that century, to electric power and new urban demands. From repairing local horseshoes they were able to repair power looms and steam machines of the nearby villages, and then learnt to build iron radiators for the Spanish market. This transformation was unusual, as many ironworks disappeared in Spain in the industrialization period ${ }^{37}$. It was also difficult, because in comparison with other industrializing regions of peripheral Europe, like Italy or Sweden, the new equipment and raw materials were expensive, access to bank credit or new energy power was neither easy nor cheap in their region, and knowledge transfer from abroad was both scarce and difficult to obtain. The second and third generations of the Roca family of Manlleu learnt new techniques by travelling during their youth to Barcelona to serve apprenticeships in the best and most innovative metalmechanic manufacturing houses, many of them founded by foreigners like Casa Alexander or Talleres Pfeiffer. The Roca family saved and led an extremely austere life in order to reinvest profits and pay the costs of technological modernization. Their marriage strategies with other iron families of the nearby villages favoured the succession process and the continuation of the small workshop. At the beginning of the $20^{\text {th }}$ century and just before the Great War some members of the fourth generation travelled to France and managed to find employment in the French subsidiary of the American Radiators Corporation (ARCo), the world leading manufacturer of iron and steel radiators and sanitary ceramic equipment. This contact abroad was fundamental for the future of the family firm: the fourth generation decided to close down their old production centre and start anew with the manufacturing of radiators for a Spanish market which was increasing its consumption of durable goods (due to the benefits derived from Spain's neutrality during the Great War and increased urbanization). There were not many competitors in Spain and this represented a great opportunity to create a new market niche. Team work was crucial: brothers Martí and Matíes led the production after close imitation of the American products observed in France, while their sister Angela took care of the accounts and younger brother Josep Roca Soler attended advanced technical studies at two of the few innovative centres established in Spain in electronics and engineering: the Instituto Electrónico de Sarrià and the

36 Luján (1992). Fernández Pérez (2006: 407-413).

37 Fernández Pérez (2004). 
Escuela de Ingenieros of Barcelona. The new generation was able to juxtapose their different abilities and skills for new purposes. Their differentiating strategy regarding Spanish competitors was to combine innovation with technical service and for this reason, in 1929, they established a cooperation agreement with the big US corporation from which they had learnt the new path of industrial activity: ARCo. This agreement meant sharing ownership (51 per cent for the US corporation), but led them to leadership in the Spanish radiator and sanitary ceramic equipment market for most of the $20^{\text {th }}$ century. Today, they continue this strategy of cooperation abroad and are world leaders in their sector.

The great diversity of economic activity in Catalonia was not easily replicated in other regions where a few specialized market niches developed in strong connection with the endowment of natural and human resources ${ }^{38}$. Studies for the entrepreneurial provinces of Biscay and Guipúzcoa, in the Basque Country, have focused on the families which, over generations, have been involved in mining, shipbuilding, banking, electricity, and metal and mechanical industries: Ybarra, Chávarri, Echevarría, Olábarri, Lequerica, Aznar and others. The small family workshops that contributed so much to the emergence of industrial districts specialized in shotguns, bikes, and other special metal manufactures, in places such as Éibar, Placencia, Ermua or Elgóibar have also attracted the attention of business historians in recent years ${ }^{39}$. Family capitalism was also the engine of growth and secular specialization in the sectors of wine and canned vegetables in the neighbouring, dynamic regions of Rioja and Navarre (Trevijano, López de Heredia, Palacios, Chivite, and others). Yet agriculture was not the only source of business initiatives. Huarte in Navarre was a forerunner in one of today's most dynamic industries in Spain: construction. Some entrepreneurial families in the iron and steel-making industries which lasted more than a century appeared along the Cantabrian coast: Quijano in Santander, and Tartière and Duro in Asturias.

The use of the regional endowment of natural resources was common to all regions. It also played a role in Galicia where, from the late $19^{\text {th }}$ century on, an expansive, internationally competitive salting industry emerged with the assistance of foreign technology, Catalan family networks and enterprising local families (Curbera, Alonso, Barreras, Massó, Portals, Godoy, Pereira and Calvo). Shipbuilding (Barreras) and banking (Pastor) were some of the spillovers of this sea-based industry ${ }^{40}$. The most durable and successful entrepreneurial families were also those

\footnotetext{
38 A recent approach is García Ruiz and Manera (eds.) (2006).

39 Valdaliso (1991 and 2006), Díaz Morlán (2002), Goñi (2007).

${ }^{40}$ Carmona Badia (coord.) (2006)
} 
which went abroad and received foreign technological influences and those which at the same time gathered families, friends and neighbours to lead processes of change, as was the case of Quijano in Los Corrales de Buelna. Quijano was a lawyer with aristocratic origins and inherited wealth who travelled to France in the 1870s and started metal production in his agricultural region of Cantabria. He used capital from his family (mother-in-law, uncle, and close neighbouring friends), the political influence his brother had in Madrid (sharing an apartment with Prime Minister Maura) and the personal support of a Catholic priest who provided a reliable workforce from the agricultural villages of the region ${ }^{41}$.

In Valencia and Murcia a large number of historical family firms were created in a similar way on the eve of the Spanish Civil War ${ }^{42}$. Many of these firms operated in relatively new industries such as metallurgy (Devís), toy manufacturing (Payá), wood, cement (ValencianaSerratosa), ceramics (Nolla), chemical fertilizers and motion pictures (Cifesa-Casanova). The tradition of ceramics in Valencia and Barcelona was indeed a key part of the success of engineer Rafael Guastavino who built more than 400 hallmark buildings in New York and Boston with the firm he created in the US in the late $1880 \mathrm{~s}$ and early years of the $20^{\text {th }}$ century. This firm survived until the 1960s under the leadership of his son ${ }^{43}$. In Murcia, where a booming mining and metallurgical industry had positive effects on the business landscape in the $19^{\text {th }}$ century, many families seized opportunities in auxiliary industries such as glass and ceramics (Valarino). It was, however, in the traditional sector of the food industry, also resource-based and less capital-intensive, where most family firms flourished since the mid century in Murcia: wine in the Jumilla region, canned vegetables (Moreno, Montesinos, GómezTornero and Cobarro), and paprika (Albarracín-La Estrella and FloresMuelas). The manufacture and commercialization of paprika became a booming sector with some 47 firms on the eve of the Great War. Largely dominated by family owned and managed businesses, this industry quickly responded to the increased demand for esparto sacks (in which paprika was usually transported).

In Andalusia the main economic activities were related with mining and agriculture. The best known and most durable Spanish entrepreneurial families focused on land and property and wholesale and international trade, whereas those dealing with mining, metal, textiles and

\footnotetext{
41 Fernández Pérez (2005).

42 This regional overview is based on the excellent work of J. Vidal Olivares on Valencia and J. M. Martínez Carrión on Murcia in García Ruiz and Manera (dirs.) (2006).

${ }^{43}$ Guastavino registered 24 patents in the US. Tarragó (ed.) (2002).
} 
food, including some famous names (Larios, Málaga wine exporters, Carbonell) were rather exceptional. In Western Andalusia, particularly in Cádiz, the end of the colonial monopoly led many tradesmen to reshape their activities. The production and commercialization of sherry in the Jerez-Puerto de Santa María-Sanlúcar de Barrameda triangle was the main occupation of enterprising dynasties of foreign origins such as the González (of González \& Byass), Terry and Osborne ${ }^{44}$.

Family entrepreneurship was also remarkable in the islands ${ }^{45}$. The Fluxà family, in Majorca, constitutes one of the most interesting cases of adaptation, diversification and survival; from footwear to tourism. In the Canary Islands, where much of the pre-war entrepreneurship involved agricultural exports (tomatoes, bananas, tobacco, salted fish or the salting industry), foreign investors were far more active than local businesspeople.

Old Castile family firms were much more inward-looking in a region where the economic basis was extensive agriculture (wheat and flour). Neither this situation nor the prevalent equalitarian inheritance practices favoured the continuity of family firms. By the end of the $19^{\text {th }}$ century, however, many entrepreneurial families innovated and diversified in fields as diverse as winemaking (Calderón, Roiz and Lecanda-Vega Sicilia), metallurgy (Talleres del Duero and Talleres del Tormes), and chemicals (Mirat). South of Madrid, in the New Castile region, family firms focused on agriculture (Gonsálvez and Pastor), knives (La Industria and Sánchez, López), and footwear (Coloma). Interestingly, much of the local wine and oil industry was promoted by Catalan and Basque individuals and families. Spanish migration was also a key to the development of family capitalism in Madrid. Particularly successful were the firms involved in the manufacture and trade of luxury goods, banking (Urquijo), publishing (Rivadeneyra and Urgoiti), and consumer goods such as chocolate (Matías López), beer (Mahou and El Águila), and soap (Gal and Floralia) ${ }^{46}$.

The neutrality of the First World War years plus the protectionist industrial policies of the 1920s together with the effects of technology transfer (such as declining prices) during the first decades of the $20^{\text {th }}$ century, opened new market niches like yoghourt production (the Carasso family who established the first Danone firm in Barcelona), reduced the number of small domestic competitors and fostered association with other regional producers (see the case of Quijano in metal

\footnotetext{
44 Fernández Pérez (1999).

45 García Ruiz and Manera (dirs.) (2006).

46 We have drawn extensively on the work of J. Moreno and J. L. García Ruiz on Castile and Madrid in García Ruiz and Manera (dirs.) (2006) in this paragraph.
} 
production in Cantabria). In a few cases the process provided a stimulus to go international (Salvat and Miquel Avellí in publishing or cork production provide examples).

The military upheaval of 1936 and the defeat of the legal Republican government in 1939 stopped technological progress and internationalization until at least the early 1950s. In compensation, those firms able to survive benefited from the new rules established in taxation, the labour market, finance, and reduction of foreign competitors: the domestic market was reserved for the largest Spanish producers.

\subsection{The adaptation of family firms to an isolationist economy}

With Franco's policies, the survival of many firms would be conditioned not so much by ideology as by their size and ability to cope with the interventionist, arbitrary, and corrupt practices of the new authorities. Whether family owned or not, firms had to devote great efforts to access raw materials, import licences and privileged information ${ }^{47}$. Bribing and smuggling became epidemic.

Three different paths of growth opened up for family firms in Spain. Firstly, those family firms able to provide auxiliary products and services to the new public holding, the INI (Instituto Nacional de Industria, created in 1941) had an opportunity to develop. A second path of growth was followed by those family firms able to lobby in Madrid to buy foreign firms or foreign-controlled shares of their firms at low prices. Usually both paths of growth were open to family firms of medium or large size before the war, who had good networking skills enabling them to connect with the new military authorities. A third path of growth was taken by more modest entrepreneurs who founded new family firms in sectors with relatively low entrance costs and low import requirements.

Two examples of firms which took the first path were Quijano in the region of Cantabria, and Rivière in Catalonia, both founded in the last third of the nineteenth century. Quijano, a pioneer of iron and steel wire manufactures, created in 1873, progressively reduced traditional production and invested in the manufacturing of auxiliary metal products and motors for the automobile industry. The change was made after the death of the founder and with professional engineers as the new production managers. In 1950, Quijano's new CEO, Alfonso Alvarez Miranda, was appointed and technological transformation accelerated ${ }^{48}$.

47 Catalan (1995 and 2003).

48 Quijano (1998: 51-55). Archivo de Trefilerías Quijano in Los Corrales de Buelna: «Dossiers de prensa sobre la empresa». 
Rivière, also a steel wire producer, introduced the production of special springs for car seats for SEAT and special security fences for the U.S.A. military bases set up in Spain in the 1950s. Rivière introduced Bedaux scientific production methods in these years to adapt to the new demand ${ }^{49}$.

Roca Radiadores provides an example of the second path of growth of family firms in this period, that of nationalization of foreign shares of the firm. The Catalan firm Talleres Roca, S. A., manufacturer of metal radiators, had signed a partnership with the U.S.A. firm American Radiator Company (ARCo.) in 1929 and created Roca Radiadores, S. A., ARCo. holding 51 per cent of the shares and key control of the management in the hands of U.S.A. managers. The three Roca Soler brothers maintained managerial responsibilities in the factory (Matíes and Martí) and on the administrative board (Josep). After the war, the law of 24th November 1939 prohibited foreign investors from owning more than 25 per cent of the total capital of Spanish firms and the Instituto Español de Moneda Extranjera was created to restrict the use of foreign currency and avoid economic collapse after the war. Thus, ARCo. was forced to reduce its ownership in the firm and finally sold everything to the minority Spanish partners ${ }^{50}$.

Not many family firms able to survive the war and start again in the isolationist times of the 1940s had the money or the political influence that the above-mentioned family firms enjoyed to get special bank loans and import permits and invest to obtain successful results in a poor, though protected, domestic market. The most common path of growth for family firms in these years was probably the third one, based on specialization in market niches in which state permits or foreign imports were not strategically needed, particularly in the consumer goods industries or light construction materials. This specialization was cheaper and easier as a business strategy in the 1940s, in the face of import difficulties and with a good endowment with natural resources and human capital specialized in these sectors. Great efforts and team work were, however, required to adapt to the new market situation. Spanish foreign trade declined until the 1950s and salaries were low. Infrastructures did not improve much despite the need for

49 Bedaux systems through the consultant firm Gombert. Archivo Moreda Rivière Trefilerías in Cerdanyola del Vallés: «Organización de la empresa Rivière». Also Fernández Pérez (2004).

50 This provoked a lively debate in the North American Division of Monetary Affairs and the U.S.A. Treasury, according to documents of the National Archives and Records Administration, Record Group 56, Records relative to Spain, Box 24 «10/5/1944 Proposed sale of subsidiary of American Radiator and Standard Sanitary Corp. to Roca-Soler Family». This reference was generously provided by Adoración Alvaro. See also Luján (1992: 181-185). 
roads and railways to connect the country. Many small workshops had to stop production due to shortages of power and raw materials ${ }^{51}$. Family firms able to manufacture and sell imaginative cheap food, small metallic pieces and machinery or cheap (and chaste) publications to feed the imagination in these conditions were able to blossom. In 1937 Lluis Carulla started manufacturing his Gallina Blanca concentrated soup cubes, introduced into Spain by the Swiss firm Maggi, and made technology transfer from abroad to improve the product using radio, and later also $\mathrm{TV}$, advertisements to reach the fragmented and badly connected Spanish consumers ${ }^{52}$. Another example of this third type of family firm was Alfonso Soláns Serrano with his Saragossa workshop manufacturing metal frames for beds (Pikolin) in $1948^{53}$. Or Andreu Costafreda Montoliu, a baker working on his own since 1928, who suffered the loss of his business after the war and realized that this sector of small and medium family firms could only grow through collective action. He created Compañía Auxiliar de Panificación, S. A., in 1945, in order to represent and legally defend Barcelona's bakers and provide them with social protection. His entrepreneurial attitude led him to found Panrico, one of the largest family firms in the second half of the $20^{\text {th }}$ century in industrial baking in Spain, which was sold to a British financial group in $2006^{54}$. Another good example is Planeta, one of the ten most important publishing corporations in the world. José Manuel Lara, from Seville, established the firm in Barcelona after the Civil War, bought the small publishing firm Editorial Tartessos in 1944 and started the publication of best sellers written by American and Spanish authors, beginning in 1952 what would become one of the most important marketing tools of the Spanish-speaking publishing world, the Planeta novel prize ${ }^{55}$. Mier, a firm founded by the two Asturian brothers Pedro and Ramón Mier Allende as a radio shop (Radio Lyra) in Barcelona in the late 1940s is another example. The firm performed radio repairs and during the 1950s and 1960s slowly developed innovative car antennas bought by foreign multinationals and auxiliary products for radio and TV. During the 1960s and 1970s the excellent relationships of the Mier brothers with foreign world leaders in telecommunications (Philips and Fuba), their promotion of associations in their sector and their stable links with Catalan technical universities helped them become one of the few Spanish family firms providing auxiliary products for the European Airspace Agency

\footnotetext{
1 Fernández Pérez (2007)

2 Cabana (2006: 515-516)

53 Fernández Pérez (2007).

54 The Brand Council (2002: 38).

55 Prieto (2006: 589-590).
} 
(ESA) in $1985^{56}$. José María Ballvé, a final example, created Conservera Campofrío in the city of Burgos in 1952. The firm specialized in meat manufacturing and from the outset made great efforts to improve its commercialization channels. From the traditional sales representative of the $19^{\text {th }}$ century, the firm invested in their own sales agencies in the major provincial cities and in trucks of their own ${ }^{57}$.

Consumer goods industries or light construction equipment did not compete directly either with state owned firms or with (forbidden) foreign firms, did not depend as much as capital goods industries did on imported inputs and technology, and met a fast growing, domestic and mainly urban demand. This was to be the very basis of the competitive advantage of Spanish family firms during the second half of the $20^{\text {th }}$ century and to the present day. After the 1950s and during the 1960s they flourished in construction, printing and publishing, food and beverages, soap and perfumery, and light metallurgy. Those firms which either established enduring relationships with foreign partners or ventured into foreign markets in spite of the prevailing adverse circumstances, became leaders at home. Such cases, in the 1960s and early 1970s, are the food manufacturing firms Panrico (the Costafreda family), Campofrío (the Ballvé family), Calvo (the Calvo family), and Gallina Blanca (the Carulla family), and the continuous efforts in this direction of $19^{\text {th }}$ century internationalized family firms in the beverage industry such as Freixenet (the Ferrer family), González \& Byass and Osborne. The efforts made to build brands and internationalize were also remarkable in the perfume (the Puig family) and pharmaceutical (the Esteve family) industries in Catalonia ${ }^{58}$.

Growth needed new strategies and structures as in managerial corporations. Organizational routines, lay-outs and new distribution channels started to appear and adapt to the new realities of increased complexities in production and distribution. However, increases in levels of management professionalism took place slowly in comparison with managerial corporations and with a strong component of family individuals. In the most capital intensive family firms this process could lead to conflicts with shop-floor employees and with non-family managers ${ }^{59}$. New organizational routines were often the result of technology transfer from abroad which was increasingly possible after 1959 through partnerships with foreign firms. This strategy allowed growing family firms to modernize lay-outs without losing ownership and control. This began

\footnotetext{
56 Mier (2002).

57 The Brand Council (2002: 26).

58 A short overview of the first generations of these family firms in Catalonia is included in the edited volume of Cabana (ed.) (2006).

59 Guillén (2005), Fernández Pérez (2004).
} 
to happen in the 1960s, for instance, in Agrolimen with the American Purina in the food industry, Rivière, S. A., with Belgian firm Bekaert in steel wire manufacturing, Mier Comunicaciones with German firm Fuba, and many others in the chemical and engineering sectors. Depending on each case, these agreements provided improvements in technology, marketing and management. Another strategy to get professional managers among the family members of big family firms in the 1950s and 1960s was the promotion of private business schools (ESADE and IESE were created in Barcelona in 1958). More rarely in these years, senior family managers sent younger offspring to receive advanced technical and professional training abroad, though when this happened it helped technology transfer as was the case in Rivière or Celsa.

At regional level, through the 1950s, 1960s and 1970s, Catalonia remained a home to many of the most outward-looking family firms of the time. Some of the already mentioned firms performed well during the early phase of the dictatorship: Freixenet, Codorniu, Roca, Rivière, Torras, Ribera and Myrurgia. Others carried out successful transformations: Uriach, Esteve, Andreu, Puig, Torras and Roca. Others built their firms from scratch: Planeta, Carulla, Ferrer, Almirall, Pujol-Ficosa and Rubiralta-Celsa. Many used US adapted techniques of productivity gains from textbooks or Spanish engineers trained abroad who worked in the public and private sector ${ }^{60}$.

In the Basque Country, the increasing demand for intermediate and capital goods since the 1950s has paved the way for many new private initiatives such as Luzuriaga, Aristrain and Ucín, while it has provided old firms such as Echevarría with new opportunities to expand. There are several examples of old and new firms specializing in services, the most interesting probably being Sener, a leading international engineering firm founded by the Sendagorta family in $1956^{61}$. Basque family capitalism also kept growing in the food industry: Koipe, Savin, Garavilla, Knörr, Elgorriaga and Artiach. In Galicia, a major change in the local family capitalism, firmly based on canned fish, was the socalled dairy-drive and the frozen fish-drive. It was in the second half of the last century that some canned fish firms became vertically integrated groups like the family firm Calvo, while other families ventured into the promising field of frozen fish by creating vertically integrated groups like Fernández Sousa with Pescanova, or into the dairy industry ${ }^{62}$. Brilliant as it is, this development has been overshadowed by the more

\footnotetext{
60 Carmelo María Cabré Rabadá served in these years as consultant of scientific methods of production for many Catalan family firms and has a vast archive of firm records of these years in Barcelona.

61 Gándara (2006).

62 Carmona Badia (coord.) (2006).
} 
recent yet astounding rise of the local fashion industry, whose flagship is Inditex (Zara and other brands), of the Ortega family whose second generation is about to take over.

In Valencia, local family firms focused on agro business and consumer goods (footwear, clothing, leather, furniture, cork, toys, and icecream). The main reason was that knowledge and expertise had accumulated over generations in these industries and they were very much in need of the implementation of advanced technologies. Family capitalism, however, also diversified by entering the paper and cement industries and retailing/distribution later on. The fast growth of the Valencian economy during the second half of the past century explains, for instance, the development of Mercadona, Spain's leading supermarket chain, founded by Francisco Roig in the 1970s out of his family's meat business. The older and more conspicuous Serratosa family, founder of Valenciana de Cementos, exemplifies the flexibility of Valencia family capitalism. Serratosa entered the aviation business in the 1990s, seizing the twofold opportunity of liberalization in the sector and the astounding development of the local tourism industry. Their airline, Air Nostrum, has been operating as a franchise of Iberia since 1999.

In Murcia, many family firms specialized in canned vegetables and fruit while paprika underwent a severe crisis mainly due to the policy of self-sufficiency which made it impossible to compete on the international market. In the late 1950s, the situation started to look up for the traditional local industries. As in most of Spain, here the engines of growth were the expansion of the domestic market and the increasing integration of the Spanish economy into today's European Union. In the 1970s, big family firms such as García-Carrión and Roque-García-Martínez already existed.

In spite of the dramatic growth of tourism in the Spanish islands in general, it was above all in the Balearic Islands, not the Canary Islands, where indigenous family capitalism became prominent. In the decades following the civil war there was a substantial transfer of human and financial capital from the traditional industries (textiles and footwear) to Spain's principal industry, tourism. The Fluxà shoemaking family remains a case in point. Their diversification started as early as 1950 with the founding of Viajes Iberia (now Iberojet, one of the big names in the Spanish tourism business). The two other big names are Barceló and Escarrer.

In Castile a very interesting restructuring process has taken place since the mid $20^{\text {th }}$ century. On the one side, the wool textile industry around Béjar, in the Salamanca province, developed notably thanks to increased investment from its Catalan partners. On the other, as the traditional wheat flour industry declined, new family firms appeared in the 
related fields of biscuits, pasta, pork meat, oil, chocolate, and dairy products. The evolution of those firms (Fontaneda, Gullón, Loste, Revilla, Campofrío, Martínez, Dulciora, Trapa, Pascual and Elosúa) based first in the local, then in the national and more recently in the international market. Their adaptation to the liberalization of the Spanish economy has not been easy due to competition from multinational groups and traumatic succession processes: Fontaneda and Loste were sold to Nabisco; Siro to Danone; Dyc to Osborne; Dulciora to Cadbury; Revilla to Unilever and then to Campofrío. Surviving firms have successfully managed succession processes, creating vertically integrated groups (Pascual, Gullón and Campofrío), and eventually buying local firms from foreign multinational groups (Fontaneda and Revilla). In New Castile, south of Madrid, family firms faced the irreversible decline of some industries (such as Albacete knives) and the development of food and beverage industries such as Valdepeñas winemakers and cheese makers García Baquero and Forlasa.

\section{CONCLUSIONS}

Family firms performed very dynamically during the golden age of the managerial corporation. Spain is a strong case in support of this argument. Today, half of the largest Spanish multinationals are familyowned, half of the largest Spanish firms are family firms and almost 25 per cent of these large family firms are not the result of recent integration processes in the world markets, but heirs of a long tradition of survival and adaptation.

Like other large family firms around the world, they are highly specialized in market niches where they have built long term intangible assets like reputation, brands, and negotiation skills, especially in food and beverages, construction, engineering, chemicals and pharmaceuticals, light metal industries, ceramics and fashion.

Our research reveals that most of them were established before the golden age of capitalism and that the most fertile periods for the creation of enduring family firms were the first third of the $20^{\text {th }}$ century and the first two decades of Franco's military dictatorship, two highly protectionist and isolationist periods of Spain's economic history.

Among the key factors that explain this chronology we have stressed the protectionist umbrella of the two dictatorships, and the exceptional availability of markets for large Spanish firms -international markets during World War I and the domestic market during the 1940s and 1950s - . The state indirectly benefited large family firms by providing general labour and fiscal advantages and not considering certain sectors 
strategic. The examples of car producers Hispano-Suiza (the Mateu family) and Elizalde (the Elizalde family) reveal how difficult survival could be in industries which were so attractive for the military authorities $^{63}$. On the other hand, knowledge transfer was often possible because of the existence of a tradition of personal relationships with family firms from other countries which preceded the civil war. Last but not least in significance among the external factors affecting survival and endurance, was regional endowment with natural and/or human resources which provided fertile ideas and resources (as the examples of Freixenet or Codorniu reveal) ${ }^{64}$. One should not underestimate the flexibly innovative character of family firms (capable of sacrificing their share of yearly profits for the long term survival of the family, as in the cases of Carasso and Roca), team work within the family as in the case of the Puig family of perfume manufacturers, and a common set of identity and interests with the different employees of the firm as the papermakers Miquel i Costas demonstrated.

\section{BIBLIOGRAPHY}

Actualidad Económica (2006).

Aymerich, R. (2006): "Isaac Carasso», in F. CABANA (ed.), Cien empresarios catalanes, Madrid: LID, pp. 343-344.

Bıвко, S. (2002): "Spanish Lobbying», in Families in Business. Special Issue "Spain», vol. 1, issue 6, November, p. 45.

Braudel, F. (1982): Civilization and Capitalism, 15th to $18^{\text {th }}$ centuries, vol. II, The Wheels of Commerce. NY: Harper and Row.

CABAna, F. (2006): "Pau Salvat i Espasa», and «Lluis Carulla i Canals», in F. CABANA (ed.), Cien empresarios catalanes, Madrid: LID, p. 331 and pp. 515-516.

CABANA, F. (ed.) (2006): Cien empresarios catalanes, Madrid: LID.

CARMONA BADIA, X. (coord.) (2006): Empresarios de Galicia, Coruña: CIEFFundación Caixa Galicia.

CASEY, J. (1999): Early Modern Spain: A Social History, Routledge: Oxford.

Casson, M., and Godley, A. (eds.) (2000): Cultural Factors in Economic Growth, Berlin-Heidelberg-New York: Springer-Verlag.

Castells, M., (2000): The Information Age: Economy, Society and Culture, Malden: Massachusetts, vol. I, The Rise of the Network Society (2004), vol. 2, The Power of Identity (2000), vol. 3, End of Millenium.

Catalan, J. (1995): La economía española en la segunda Guerra mundial, Barcelona: Ariel.

- (2003): «La ruptura de posguerra y la industrialización 1939-1975», in NADAL (dir.) (2003): 233-388. (2006)

${ }^{63}$ Currently Jordi Nadal is studying the history of Hispano Suiza. For Elizalde, Catalan 64 Valls (2006). 
- (2006): «Artur Elizalde i Rouvier», in F. CABANA (ed.), Cien empresarios catalanes, Madrid: LID: 311-319.

Chander, A. D. Jr. (1994): Scale \& Scope: The Dynamics of Industrial Capitalism, Cambridge: Harvard University Press.

Colli, A. (2003): The History of Family Business 1850-2000, Cambridge: Cambridge University Press.

Colli, A.; Fernández Pérez, P., and Rose, M. B. (2003): «National Determinants of Family Firm Development? Family Firms in Britain, Spain and Italy in the Nineteenth and Twentieth Centuries», Enterprise and Society, 4, 1, pp. 28-64.

CORONA, J., and CASADO, F. (2002): «The IEF», in Families in Business. Special Issue "Spain», vol. 1, issue 6, November, pp. 40-41.

Chandler, A. D. Jr.; Amatori, F., and Hikino, T. (eds.) (1997): Big Business and the Wealth of Nations, Cambridge: Cambridge University Press.

Díaz Morlán, P. (2002): Los Ybarra. Una dinastía de empresarios 1821-2001, Madrid: Marcial Pons.

FERNÁNDEZ PÉREZ, P. (1996): «Bienestar y pobreza. El impacto del sistema de herencia castellano en Cádiz, el emporio del orbe 1700-1812», Revista de Historia Económica, XV, 2, pp. 243-268.

- (1997): El rostro familiar de la metrópoli. Redes de parentesco y lazos mercantiles en Cádiz, 1700-1812, Madrid: Siglo XXI de España Editores.

- (1999): "Challenging the Loss of an Empire: The González \& Byass of Jerez», Business History, 41, 4: 72-87.

- (2004): Un siglo y medio de trefilería en España. Historia de Moreda y Rivière, Barcelona: MRTA-Trivium.

- (2005): «Redes familiares e innovación tecnológica en la España de fines del siglo XIX: los casos de José María Quijano y Francisco Rivière», Historia Contemporánea, 2, 31: pp. 439-456.

- (2006): «Angela, Matías, Martin y Josep Roca Soler», in F. Cabana (ed.), Cien empresarios catalanes, Barcelona: LID.

- (forthcoming): «Pikolin» in F. RIBERA RAICHs (coord.), Empresas, empresarios y dirigentes, Barcelona.

Fernández Pérez, P., and Puig, N. (2004): «Knowledge and Training in Family Firms of the European Periphery», Business History, 41.

Fernández Pérez, P., and Hamilton, E. (2007): "Gender and Family Firms: An Interdisciplinary Approach». Document de Treball de l'Espai de Recerca en Economia de la Facultat d'Econòmiques de la Universitat de Barcelona, http://www.ere.ub.es/dtreball/E07171.rdf/view.

FERNÁNDEZ PÉREZ, P., and Rose, M. B. (eds.) (2007): Innovation and Entrepreneurial Networks in Europe, Oxford: Routledge.

Galambos, L. (2005): "Recasting the Organizational Synthesis: Structure and Process in the Twentieth and Twenty-First Centuries», Business History Review, 79, pp. 1-38.

Galve, C., and Salas, V. (2003): La empresa familiar española, Bilbao: Fundación BBVA.

Gálvez, L., and Fernández Pérez, P. (2007): «Female Entrepreneurship in Spain in the $19^{\text {th }}$ and $20^{\text {th }}$ centuries", Business History Review, 81 .

GándarA, A. (2006): Sener. La historia de su tiempo 1956-2006, Salamanca: Editorial Kadmos. 
BONSAIS IN A WILD FOREST? A HISTORICAL INTERPRETATION OF THE LONGEVITY...

García Delgado, J. L. (dir.) (1999): España, Economía: ante el siglo XXI, Madrid: Editorial Espasa-Calpe.

García Ruiz, J. L., and Manera, C. (dirs.) (2006): Historia empresarial de España: un enfoque regional en profundidad, Madrid: LID.

Goody, J. (1983): The development of the family and marriage in Europe, NY: Cambridge University Press.

GranovetTER, M. (1995): "Coase Revisited: Business Groups in the Modern Economy», Industrial and Corporate Change, 4, 1, pp. 93-130.

GoÑI, I. (2006): «Evolución de la industria armera vasca (1876-1969): un enfoque a largo plazo», in P. PASCUal Doménech and P. Fernández Pérez (2007), Del metal al motor. Innovación y atraso en la historia de la industria metal-mecánica en España, Bilbao: Fundación BBVA.

Guillén, M. (1994): Models of Management: Work, Authority, and Organization in a Comparative Perspective, University of Chicago Press.

Gutiérrez, M. (2006): «Antoni Miquel i Costas», in F. CABAna, Cien empresarios catalanes, Madrid: LID, 198-204.

Howorth, C.; Rose, M., and Hamilton, E. (2006): «Definitions, Diversity and Development: Key Debates in Family Business Research», in M. CASson (ed.), Oxford Handbook of Entrepreneurship, Oxford: 225-247.

James, H. (2006): Family Capitalism. Wendels, Haniels, Falcks and the Continental European Model, Cambridge MS and London: The Belknap Press of Harvard University Press.

Jones, G., and Rose, M. (1993): «Family Capitalism», Business History, vol. 35.

López Carrillo, J. M. (2006): «Damià Mateu Bisa», in F. Cabana, Cien empresarios catalanes, Madrid: LID, 264.

Luján, N. (1992): La lucha contra el frío y el calor, y a favor de la higiene. Contribución de una familia de industriales catalanes a lo largo de 75 años, Barcelona: Montserrat Mateu Taller Editorial.

Mendoza, A. (1982): Ferrocarriles y cambio económico en España (1855-1913), Madrid: Alianza.

Mier (2002): Llegar más lejos, Barcelona: Mier Comunicaciones.

Moreno Castaño, B. (2006): «Joseph Vilà i Marqués», in F. CABAna, Cien empresarios catalanes, Madrid: LID, 349.

Miller, D., and Le Breton-MilleR, I. (2005): Managing for the Long Run:Lessons in Competitive Advantage from Great Family Businesses, Boston: Harvard Business School Press.

MurRaY, B. (2002): «Spain needs family brands», in Families in Business. Special Issue "Spain», vol. 1, issue 6, November, pp. 52-55.

Nadal, J., and Catalan, J. (eds.) (1994): La cara oculta de la industrialización española. La modernización de los sectores no líderes (siglos XIX y XX), Madrid: Alianza.

NADAL, J. (dir.) (2003): Atlas de la industrialización de España 1750-2000, Barcelona: Crítica-FBBVA.

NúÑEz, C. E., and ToRTElla, G. (eds.) (1993): La maldición divina. Ignorancia y atraso económico en perspectiva histórica, Madrid: Alianza.

Oliveras Samitier, J. (2006): "Joan Jorba Rius», in F. Cabana, Cien empresarios catalanes, Madrid: LID, 302-310.

Parsons, M. C., and Rose, M. B. (2004): "Communities of knowledge: entrepreneurship, nnovation and networks in the British outdoor trade 1960-1990", Business History, vol. 46 (4), pp. 606-637. 
Pascual Domènech, P., and Fernández Pérez, P. (eds.) (2007): Del metal al motor. Innovación y atraso en la historia de la industria metal-mecánica española, Bilbao: Fundación BBVA.

Prados de la Escosura, L. (1991): De imperio a nación: crecimiento y atraso económico en España (1780-1930), Madrid: Alianza.

Prieto Martín, A. (2006), "José Manuel Lara Hernández», in F. Cabana (ed.), Cien empresarios catalanes, Madrid: LID, pp. 589-593.

PuIG, N. (2003): «The Search for Identity: Spanish Perfume in the Internacional Market», Business History, 45/3, pp. 90-118.

- (2006): «La empresa en Cataluña: identidad, supervivencia y competitividad en la primera región industrial de España», in J. L. GARCía RuIZ and C. MANERA (eds.), Historia empresarial de España. Un enfoque regional en profundidad, Madrid, 2006, pp. 27-56.

- (2006): «Esteve Monegal Prat», in F. CaBana, Cien empresarios catalanes, Madrid: LID, pp. 445-455.

Puig, N., and Fernández Pérez, P. (2003): «The Education of Spanish Entrepreneurs and Managers: Madrid and Barcelona Business Schools 19501975», Paedagogica Historica, 39, 5, pp. 651-672.

QuiJano (1998): 125 Aniversario de Trefilerías Quijano, S. A. (1873-1998), Santander: Cámara de Comercio de Cantabria-Imprenta Cervantina.

Rose, M. B. (ed.) (1995): Family Business, Aldershot: Edward Elgar.

Rose, M. B., and Parsons, M. C. (2003): Invisible on Everest: Inovation and the Gear Makers, Philadelphia: Old City Publishing.

Sala, P. (2006): "Joan Miquel i Avellí», in F. Cabana, Cien empresarios catalanes, Madrid: LID, 353-361.

Stone, L. (1977): The Family, Sex and Marriage in England 1500-1800, New York: Harper\&Row.

TARRAGó, S. (ed.) (2002): Guastavino Co. (1885-1962). Registre de l'obra a Catalunya i Amèrica, Barcelona: Col.legi d'Arquitectes de Catalunya.

The Brand Council (2002): Topbrands. El libro de las grandes marcas en España, vol. I, Madrid: The Brand Council.

Valdaliso, J. M. (2006): La familia Aznar y sus negocios, Madrid: Marcial Pons.

Valls, F. (2006): «Josep Ferrer Sala», in F. CaBana (ed.), Cien empresarios catalanes, Madrid: LID, 657-664. 
BONSAIS IN A WILD FOREST? A HISTORICAL INTERPRETATION OF THE LONGEVITY...

\section{APPENDIX}

TABLE 1

THE 245 LARGEST HISTORICAL FAMILY FIRMS AND GROUPS IN SPAIN, 2005

\begin{tabular}{|c|c|c|c|c|c|}
\hline $\begin{array}{l}\text { Group } \\
\text { Name }\end{array}$ & Family & $\begin{array}{c}\text { Date of } \\
\text { foundation }\end{array}$ & Sector & $\begin{array}{c}\text { Turnover } \\
\text { (million euros) }\end{array}$ & Employees \\
\hline \multicolumn{6}{|c|}{ CATALONIA (84 FIRMS) } \\
\hline FCC & Koplowitz & $1900 / 1992$ & Construction & 7,090 & 67,562 \\
\hline Celsa & Rubiralta & 1967 & Metal & 2,757 & 5,753 \\
\hline Caprabo & Carbó & 1959 & Retailing & 2,300 & 19,100 \\
\hline Roca & Roca & $1880 / 1929$ & $\begin{array}{l}\text { Construction } \\
\text { (Sanitary } \\
\text { equipment) }\end{array}$ & 1,669 & 16,000 \\
\hline $\begin{array}{l}\text { Catalana } \\
\text { Occidente }\end{array}$ & Serra & 1864 & Insurance & 1,502 & 2,824 \\
\hline Cirsa & Lao & 1968 & Gambling & 1,155 & 11,000 \\
\hline Cobega & Daurella & 1951 & $\mathrm{~F} \& \mathrm{~B}$ & 1,125 & 1,411 \\
\hline Puig & Puig & 1914 & Perfume & 962 & 5,250 \\
\hline Almirall & Gallardo & 1944 & Pharma & 962 & 3,200 \\
\hline Planeta & Lara & 1949 & Communication & 960 & 4,725 \\
\hline $\begin{array}{l}\text { Miquel } \\
\text { Alimentació }\end{array}$ & Miquel & 1925 & $F \& B$ & 836 & 3,700 \\
\hline Ficosa & Pujol, Tarragó & 1976 & Motor & 824 & 6,550 \\
\hline Esteve & Esteve & 1929 & Pharma & 818 & 2,469 \\
\hline Panrico & Costafreda & $\begin{array}{l}1960 \text { s } \\
\text { (sold 2006) }\end{array}$ & $F \& B$ & 731 & 8,284 \\
\hline Damm & Coll & $1876 / 1910$ & $F \& B$ & 656 & 1,785 \\
\hline Condis & Condal & 1961 & $\mathrm{~F} \& \mathrm{~B}$ & 652 & 4,650 \\
\hline Arbora Holding & Carulla & 1978 & Chemicals & 650 & 125 \\
\hline Comsa & Miarnau & 1934 & Construction & 642 & 1,030 \\
\hline Copisa & Cornadó & 1961 & Construction & 637 & 627 \\
\hline Molins & Molins & 1929 & $\begin{array}{c}\text { Construction } \\
\text { (concrete) }\end{array}$ & 594 & 2,485 \\
\hline Borges & Pont & 1896 & $F \& B$ & 540 & 1,082 \\
\hline Grífols & Grífols & 1940 & Pharma & 524 & 3,443 \\
\hline Colomer & Colomer & $1924 / 2000$ & Perfume & 486 & 2,310 \\
\hline Uniland & Rumeu, Fradera & $1896 / 1901 / 1973$ & $\begin{array}{c}\text { Construction } \\
\text { (concrete) }\end{array}$ & 472 & 1,01 \\
\hline Tarradellas & Tarradellas & 1983 & $\mathrm{~F} \& \mathrm{~B}$ & 424 & 950 \\
\hline Emte & Sumarroca & 1961 & Construction & 400 & 2,020 \\
\hline Freixenet & Ferrer-Bonet & 1861 & $\mathrm{~F} \& \mathrm{~B}$ & 379 & 1,323 \\
\hline
\end{tabular}


PALOMA FERNÁNDEZ PÉREZ/NÚRIA PUIG RAPOSO

\begin{tabular}{|c|c|c|c|c|c|}
\hline $\begin{array}{l}\text { Group } \\
\text { Name }\end{array}$ & Family & $\begin{array}{c}\text { Date of } \\
\text { foundation }\end{array}$ & Sector & $\begin{array}{c}\text { Turnover } \\
\text { (million euros) }\end{array}$ & Employees \\
\hline Nutrexpa & Ferrero & 1940 & $F \& B$ & 327 & 1,333 \\
\hline Bon Preu Sau & Font & 1974 & Retailing & 315 & 1,918 \\
\hline Godó & Godó & 1881 & Communication & 311 & 1,500 \\
\hline $\begin{array}{l}\text { Editorial } \\
\text { Prensa Ibérica }\end{array}$ & Moll & 1872 & Communication & 309 & \\
\hline Mecalux & Carrillo & 1969 & $\begin{array}{l}\text { Construction } \\
\text { (logistics) }\end{array}$ & 292 & 2,170 \\
\hline Ferrer & Ferrer-Salat & 1947 & Pharma & 274 & 1,174 \\
\hline Agrolimen & Carulla & 1937 & $F \& B$ & 261 & 520 \\
\hline Chupa Chups & Bernat & 1958 (sold 2005) & $F \& B$ & 260 & 1,170 \\
\hline Gallo & Espona & 1946 & $F \& B$ & 226 & 436 \\
\hline Vall Companys & Vall Companys & 1967 & $F \& B$ & 221 & 89 \\
\hline Ros Roca & Roca & 1953 & Engineering & 218 & 11 \\
\hline Codorniu & Raventós & $1872 / 1926$ & $\mathrm{~F} \& \mathrm{~B}$ & 198 & 1,006 \\
\hline Soler y Palau & Soler Palau & 1951 & Engineering & 190 & 515 \\
\hline $\begin{array}{l}\text { Grupo de } \\
\text { Estampación } \\
\text { Sabadell }\end{array}$ & Bonet & 1965 & Engineering & 186 & 1,165 \\
\hline Habitat & Figueras & 1953 & Real estate & 180 & 156 \\
\hline Torres & Torres & 1870 & $\mathrm{~F} \& \mathrm{~B}$ & 176 & 800 \\
\hline Frigicoll & Coll & 1967 & Retailing & 175 & 323 \\
\hline Hesperia & Castro & 1971 & Tourism & 171 & 3,300 \\
\hline $\begin{array}{l}\text { Alimentaria } \\
\text { de Guissona }\end{array}$ & Alsina & 1959 & $\mathrm{~F} \& \mathrm{~B}$ & 168 & 174 \\
\hline $\begin{array}{r}\text { Superficies de } \\
\text { Alimentación } \\
\end{array}$ & Sorli & 1979 & Retailing & 165 & 1,130 \\
\hline HUSA & Gaspart & 1930 & Tourism & 162 & 2,800 \\
\hline Lacer & Andress & 1949 & Pharma & 160 & 600 \\
\hline Lípidos Santiga & Soler & 1968 & Textiles & 159 & 106 \\
\hline $\begin{array}{l}\text { Miquel } \\
\text { y Costas }\end{array}$ & Miquel & 1725 & Paper & 157 & 913 \\
\hline Uriach & Uriach & 1838 & Pharma & 153 & 753 \\
\hline Simón & Simón & 1916 & $\begin{array}{l}\text { Electrical } \\
\text { equipment }\end{array}$ & 145 & 930 \\
\hline Indo & $\begin{array}{l}\text { Cottet } \\
\text { y Colomer }\end{array}$ & $1902 / 1937 / 8$ & Optics & 144 & 1,722 \\
\hline $\begin{array}{l}\text { Corporación } \\
\text { Age }\end{array}$ & $\begin{array}{l}\text { Boada, } \\
\text { Gummà, } \\
\text { Masferrer }\end{array}$ & 1981 & Construction & 143 & 1,025 \\
\hline $\begin{array}{l}\text { Colomer } \\
\text { Munmany }\end{array}$ & Colomer & 1792 & Leather & 140 & 913 \\
\hline
\end{tabular}


BONSAIS IN A WILD FOREST? A HISTORICAL INTERPRETATION OF THE LONGEVITY...

\begin{tabular}{|c|c|c|c|c|c|}
\hline $\begin{array}{l}\text { Group } \\
\text { Name }\end{array}$ & Family & $\begin{array}{c}\text { Date of } \\
\text { foundation }\end{array}$ & Sector & $\begin{array}{c}\text { Turnover } \\
\text { (million euros) }\end{array}$ & Employees \\
\hline Aceros Bergara & Boixareu & 1945 & Metal & 132 & 102 \\
\hline Titán & Folch & 1917 & Chemicals & 137 & 624 \\
\hline $\begin{array}{l}\text { Synthesia } \\
\text { Española }\end{array}$ & Zuloaga & 1964 & Chemicals & 127 & 203 \\
\hline Vichy Catalán & $\begin{array}{l}\text { Renat, } \\
\text { Casa, } \\
\text { Murla, } \\
\text { Montalat, } \\
\text { Lluansí }\end{array}$ & 1901 & $\mathrm{~F} \& \mathrm{~B}$ & 122 & 725 \\
\hline Campí y Jové & Campí y Jové & 1923 & Chemicals & 120 & 82 \\
\hline Basi & Basi & 1948 & Fashion & 111 & 415 \\
\hline Noel & Bosch & 1940 & $F \& B$ & 109 & 449 \\
\hline Cuatrecasas & Cuatrecasas & 1926 & Legal services & 106 & 350 \\
\hline Pronovias & Palatchi & $1922 / 1968$ & Textiles & 103 & 23 \\
\hline Ausa & Perramón & 1956 & $\begin{array}{l}\text { Machine } \\
\text { Manufacturing }\end{array}$ & 98 & 353 \\
\hline Comexi & Cifra & 1954 & $\begin{array}{l}\text { Machine } \\
\text { Manufacturing }\end{array}$ & 85 & 252 \\
\hline Abressa & Dude & 1971 & $\begin{array}{l}\text { Construction } \\
\text { (concrete) }\end{array}$ & 85 & 40 \\
\hline Espuña & Espuña & 1947 & $F \& B$ & 79 & 459 \\
\hline Goma Camps & Goma Camps & 1941 & Paper & 77 & 275 \\
\hline Sacresa & Sanahuja & $1960 \mathrm{~s}$ & Real estate & 75 & 69 \\
\hline Sedatex & Pich & $1886-1940$ & Textiles & 75 & 160 \\
\hline Colortex & Taberner & 1967 & Textiles & 75 & 686 \\
\hline Lamigraf & $\begin{array}{l}\text { Colomer } \\
\text { e Ibáñez }\end{array}$ & 1975 & Paper & 70 & 205 \\
\hline Casademont & Casademont & $1960 \mathrm{~s}$ & $F \& B$ & 69 & 485 \\
\hline $\begin{array}{l}\text { Prefabricados } \\
\text { Prensados }\end{array}$ & Pujol & 1979 & $\begin{array}{l}\text { Construction } \\
\text { (concrete) }\end{array}$ & 68 & 78 \\
\hline Alier & Alier & 1934 & Paper & 68 & 259 \\
\hline Murtra & Murtra & $1897-1922$ & Textiles & 67 & 316 \\
\hline Palex & Knuth & 1955 & Chemicals & 65 & 126 \\
\hline Inoxcrom & Vaqué & 1964 & Paper & 61 & 581 \\
\hline $\begin{array}{l}\text { Galerías } \\
\text { Tarragona }\end{array}$ & Tarragona & 1965 & Furniture & 55 & 374 \\
\hline AC Marca & Marca & $1922 / 1999$ & Chemicals & 52 & 254 \\
\hline Chocovic & Rius & $\begin{array}{l}1977 \\
\text { (1872 Arumí) }\end{array}$ & $\mathrm{F} \& \mathrm{~B}$ & 45 & 120 \\
\hline Kettal & Alorda & 1964 & Furniture & 40 & 500 \\
\hline
\end{tabular}


PALOMA FERNÁNDEZ PÉREZ/NÚRIA PUIG RAPOSO

\begin{tabular}{|c|c|c|c|c|c|}
\hline $\begin{array}{l}\text { Group } \\
\text { Name }\end{array}$ & Family & $\begin{array}{c}\text { Date of } \\
\text { foundation }\end{array}$ & Sector & $\begin{array}{c}\text { Turnover } \\
\text { (million euros) }\end{array}$ & Employees \\
\hline \multicolumn{6}{|c|}{ MADRID (35 FIRMS) } \\
\hline El Corte Inglés & $\begin{array}{l}\text { Álvarez, } \\
\text { Koplowitz }\end{array}$ & $1935 / 1940$ & Retailing & 15,022 & 87,610 \\
\hline Acciona & Entrecanales & $1931 / 1978 / 1997$ & Construction & 4,852 & 21,846 \\
\hline $\begin{array}{c}\text { Corporación } \\
\text { Gestamp }\end{array}$ & Riberas & 1989 & Motor & 2,395 & 10,439 \\
\hline Ebro Puleva & Hernández & $(1911 / 1998)$ & $\mathrm{F} \& \mathrm{~B}$ & 2,359 & 8,118 \\
\hline Sevelar & Larrinaga & 1964 & Distribution & 1,944 & 11 \\
\hline Bergé y Cia & $\begin{array}{l}\text { Bergé } \\
\text { y Gorbeña }\end{array}$ & 1960 & Motor & 1,722 & 2,500 \\
\hline Prisa (Timón) & Polanco & $\begin{array}{l}1958 \\
\text { (Santillana) } \\
1972 \text { (Prisa) }\end{array}$ & Communication & 1,425 & 9,114 \\
\hline $\begin{array}{l}\text { Gonvarri } \\
\text { Industrial } \\
\end{array}$ & Riberas & 1958 & Metal & 1,408 & 2,013 \\
\hline Prosegur & Gut & 1976 & Security & 1,387 & 70,838 \\
\hline $\begin{array}{l}\text { Grupo } \\
\text { Villar Mir }\end{array}$ & Villar Mir & 1987 & Construction & 1,374 & 6,688 \\
\hline Grupo SOS & Salazar & 1965 & $F \& B$ & 1,254 & 2,966 \\
\hline $\begin{array}{l}\text { Recreativos } \\
\text { Franco } \\
\end{array}$ & Franco & 1975 & $\begin{array}{l}\text { Slot machines } \\
\text { manufacturing }\end{array}$ & 1,106 & 7,450 \\
\hline Cortefiel & $\begin{array}{l}\text { Hinojosa } \\
(\text { sold 2005) }\end{array}$ & 1951 & Textiles & 975 & 8,965 \\
\hline Eulen & Álvarez & $1962 / 1978$ & Services & 877 & 58,733 \\
\hline Mahou & Mahon & 1889 & $\mathrm{~F} \& \mathrm{~B}$ & 800 & 2,109 \\
\hline Vocento & $\begin{array}{l}\text { Luca de Tena, } \\
\text { Ybarra }\end{array}$ & $\begin{array}{l}\text { 1891/1903/1909 } \\
\text { (Prensa } \\
\text { Española) } \\
\text { 1910/2001 } \\
\text { (Grupo Correo/ } \\
\text { Vocento) }\end{array}$ & Communication & 794 & 3,813 \\
\hline Ferrovial & Del Pino & $1952 / 1927$ & Construction & 760 & 3,500 \\
\hline $\begin{array}{l}\text { Técnicas } \\
\text { Reunidas }\end{array}$ & Lladó & 1959 & Engineering & 685 & 2,336 \\
\hline Nueva Rumasa & Ruiz Mateos & $2000 \mathrm{~s}$ & $F \& B$ & 600 & 16,000 \\
\hline Grupo Zeta & Asensio & 1976 & Communication & 451 & 2,342 \\
\hline Reyal & Santamaría & 1970 & Construction & 410 & 550 \\
\hline Grupo Sigla & Arango & 1965 & Restaurants & 340 & 5,108 \\
\hline $\begin{array}{r}\text { Patentes } \\
\text { TALGO }\end{array}$ & Oriol & 1942 & Transports & 299 & 1,844 \\
\hline $\begin{array}{l}\text { Europa \& } \\
\text { C. Cartones } \\
\text { de Castilla }\end{array}$ & Isidro & 1890 & Paper & 284 & 1,081 \\
\hline
\end{tabular}


BONSAIS IN A WILD FOREST? A HISTORICAL INTERPRETATION OF THE LONGEVITY...

\begin{tabular}{|c|c|c|c|c|c|}
\hline $\begin{array}{l}\text { Group } \\
\text { Name }\end{array}$ & Family & $\begin{array}{c}\text { Date of } \\
\text { foundation }\end{array}$ & Sector & $\begin{array}{c}\text { Turnover } \\
\text { (million euros) }\end{array}$ & Employees \\
\hline Flex & Beteré & $1912 / 1925 / 1956$ & Bed equipment & 182 & 1,500 \\
\hline Aceites Toledo & Rubio & 1965 & $F \& B$ & 140 & 62 \\
\hline $\begin{array}{r}\text { Grupo Arturo } \\
\text { Cantoblanco } \\
\end{array}$ & Fernández & 1898 & Services & 130 & 2,500 \\
\hline Hola & Sánchez Junco & 1944 & Communication & 123 & 140 \\
\hline $\begin{array}{l}\text { Laboratorios } \\
\text { Indas }\end{array}$ & $\begin{array}{l}\text { Arochena (sold } \\
\text { 2007) }\end{array}$ & 1950 & Chemicals & 120 & 405 \\
\hline Grupo Radisa & Díaz & 1860 & Construcction & 84 & 353 \\
\hline Zeltia & $\begin{array}{l}\text { Fernández } \\
\text { Sousa }\end{array}$ & 1939/1991 & Pharma & 82 & 619 \\
\hline Viajes Catai & Torres & 1980 & Tourism & 65 & 63 \\
\hline Grupo Einsa & Martínez & 1975 & Communication & 62 & 518 \\
\hline $\begin{array}{l}\text { Electrónica } \\
\text { Olfer }\end{array}$ & $\begin{array}{l}\text { Gimeno and } \\
\text { García }\end{array}$ & 1975 & Retailing & 55 & 20 \\
\hline \multicolumn{6}{|c|}{ VALENCIA (28 FIRMS) } \\
\hline Mercadona & Roig & 1977 & Retailing & 10,338 & 53,600 \\
\hline Nefinsa & Serratosa & $\begin{array}{c}1993 \text { (previously } \\
\text { Valenciana de } \\
\text { Cementos 1917) }\end{array}$ & $\begin{array}{l}\text { Diversified } \\
\text { holding }\end{array}$ & 621 & 1,777 \\
\hline Ros Casares & Ros & $1950 \mathrm{~s}$ & Steel & 612 & 655 \\
\hline $\begin{array}{l}\text { Compañía } \\
\text { Levantina } \\
\text { de Bebidas } \\
\text { Gaseosas } \\
\end{array}$ & $\begin{array}{l}\text { Gómez Trenos, } \\
\text { Serratosa }\end{array}$ & 1954 & $\mathrm{~F} \& \mathrm{~B}$ & 469 & 706 \\
\hline Grupo Guzmán & Guzmán & 1939 & Metal & 195 & 162 \\
\hline Pavasal & Quesada & 1956 & Construction & 194 & 730 \\
\hline $\begin{array}{l}\text { Marina } \\
\text { d'Or-Loger }\end{array}$ & Flia y Ger & 1983 & $\begin{array}{l}\text { Tourism and } \\
\text { real estate }\end{array}$ & 182 & 1,189 \\
\hline Porcelanosa & Soriano & $1956 / 1963 / 1973$ & $\begin{array}{c}\text { Construction } \\
\text { (ceramics) }\end{array}$ & 174 & 1,050 \\
\hline Andrés Faus & Faus & 1953 & Construction & 158 & 345 \\
\hline Dulcesol & Juan & $1950 \mathrm{~s}$ & $F \& B$ & 156 & 1,541 \\
\hline Famosa & $\begin{array}{l}\text { Rico, Molina, } \\
\text { Sempere }\end{array}$ & 1957 & Toys & 130 & 450 \\
\hline $\begin{array}{l}\text { Serra } \\
\text { Soldadura } \\
\end{array}$ & Serra & 1972 & $\begin{array}{l}\text { Machine } \\
\text { manufacturing }\end{array}$ & 126 & 735 \\
\hline Ballesmar & Ballester & 1949 & Construction & 125 & 164 \\
\hline Taulell & Gómez & 1967 & $\begin{array}{l}\text { Construction } \\
\text { (ceramics) }\end{array}$ & 124 & 800 \\
\hline $\begin{array}{l}\text { Juan Fornés } \\
\text { Fornés }\end{array}$ & Fornés & 1984 & $\mathrm{~F} \& \mathrm{~B}$ & 118 & 1,350 \\
\hline Sáez Merino & Sáez Merino & 1952 & Textiles & 117 & 1,788 \\
\hline
\end{tabular}


PALOMA FERNÁNDEZ PÉREZ/NÚRIA PUIG RAPOSO

\begin{tabular}{|c|c|c|c|c|c|}
\hline $\begin{array}{l}\text { Group } \\
\text { Name }\end{array}$ & Family & $\begin{array}{c}\text { Date of } \\
\text { foundation }\end{array}$ & Sector & $\begin{array}{c}\text { Turnover } \\
\text { (million euros) }\end{array}$ & Employees \\
\hline Durá Navarro & Durá & $1970 \mathrm{~s}$ & Construction & 112 & 20 \\
\hline Keraben & Benavent & 1975 & $\begin{array}{c}\text { Construction } \\
\text { (ceramics) }\end{array}$ & 106 & 600 \\
\hline Ecisa & Peláez & 1968 & Construction & 104 & 287 \\
\hline Gallego y Vilar & Gallego & 1964 & Retailing & 93 & 233 \\
\hline Grefusa & Gregori & 1980 & $F \& B$ & 93 & 664 \\
\hline Lladró & Lladró & 1954 & $\begin{array}{c}\text { Construction } \\
\text { (ceramics) }\end{array}$ & 82 & 1,000 \\
\hline Fontesad & Fontesad & 1984 & $\mathrm{~F} \& \mathrm{~B}$ & 81 & 927 \\
\hline Rafael Hinojosa & Hinojosa & 1972 & Paper & 72 & 310 \\
\hline Hiperber & Bernabeu & 1970 & Retailing & 67 & 400 \\
\hline $\begin{array}{c}\text { Fertilizantes } \\
\text { e insecticidas }\end{array}$ & Serrano & 1979 & Chemicals & 62 & 46 \\
\hline $\begin{array}{l}\text { Chocolates } \\
\text { Valor } \\
\end{array}$ & López & $1881 / 1973$ & $\mathrm{~F} \& \mathrm{~B}$ & 49 & 266 \\
\hline $\begin{array}{l}\text { Diario } \\
\text { Las Provincias. } \\
\text { Editorial } \\
\text { Federico } \\
\text { Domenech } \\
\end{array}$ & Domenech & 1866 & Communication & 40 & 199 \\
\hline \multicolumn{6}{|c|}{ ANDALUCÍA (22 FIRMS) } \\
\hline Abengoa & Benjumea & 1941 & Engineering & 3,405 & 11,082 \\
\hline $\begin{array}{l}\text { Grupo Sánchez } \\
\text { Ramade }\end{array}$ & $\begin{array}{l}\text { Sánchez- } \\
\text { Ramade }\end{array}$ & $1970 \mathrm{~s}$ & Various & 743 & 2,822 \\
\hline Grupo Pra & Romero & 1961 & Real estate & 550 & 530 \\
\hline Grupo Noga & Osuna & 1962 & Real estate & 330 & 260 \\
\hline $\begin{array}{l}\text { Osborne } \\
\text { (Distribuidora } \\
\text { y Bodegas) }\end{array}$ & Osborne & 1772 & $\mathrm{~F} \& \mathrm{~B}$ & 319 & 407 \\
\hline Grupo Amasua & Suárez & 1966 & $F \& B$ & 292 & 1,081 \\
\hline $\begin{array}{l}\text { Mariscos } \\
\text { Rodríguez } \\
\end{array}$ & Rodríguez & 1971 & $F \& B$ & 246 & 346 \\
\hline $\begin{array}{l}\text { AZVI-Contreras } \\
\text { Graciani }\end{array}$ & Contreras & 1925 & Construction & 246 & 775 \\
\hline Consentino & $\begin{array}{l}\text { Martínez } \\
\text { Consentino }\end{array}$ & 1979 & Minerals & 241 & 1,380 \\
\hline $\begin{array}{l}\text { Grupo Manuel } \\
\text { Barea }\end{array}$ & Barea & 1983 & Retailing & 222 & 210 \\
\hline Persan & Moya & 1941 & Chemicals & 221 & 451 \\
\hline $\begin{array}{l}\text { Grupo González } \\
\text { Cabello }\end{array}$ & $\begin{array}{c}\text { González } \\
\text { Cabello }\end{array}$ & 1977 & Retailing & 209 & 224 \\
\hline Grupo Ybarra & Ybarra & 1842 & $F \& B$ & 180 & 230 \\
\hline
\end{tabular}


BONSAIS IN A WILD FOREST? A HISTORICAL INTERPRETATION OF THE LONGEVITY...

\begin{tabular}{|c|c|c|c|c|c|}
\hline $\begin{array}{l}\text { Group } \\
\text { Name }\end{array}$ & Family & $\begin{array}{c}\text { Date of } \\
\text { foundation }\end{array}$ & Sector & $\begin{array}{c}\text { Turnover } \\
\text { (million euros) }\end{array}$ & Employees \\
\hline $\begin{array}{l}\text { Alimentación } \\
\text { Peninsular }\end{array}$ & Padilla & 1976 & $\mathrm{~F} \& \mathrm{~B}$ & 172 & 410 \\
\hline $\begin{array}{l}\text { Distribuidora } \\
\text { Mariscos } \\
\text { Rodríguez } \\
\end{array}$ & Rodríguez & 1982 & Retailing & 160 & 150 \\
\hline $\begin{array}{l}\text { Grupo } \\
\text { Industrial } \\
\text { Iturri } \\
\end{array}$ & Iturri & 1947 & Textiles & 150 & 887 \\
\hline $\begin{array}{c}\text { GP Manufactu- } \\
\text { ras de Acero }\end{array}$ & Bueno & 1973 & Metal & 130 & 77 \\
\hline $\begin{array}{l}\text { Ángel } \\
\text { Camacho }\end{array}$ & Camacho & 1897 & $\mathrm{~F} \& \mathrm{~B}$ & 107 & 557 \\
\hline González Byass & González & 1835 & $F \& B$ & 101 & 350 \\
\hline $\begin{array}{l}\text { Hierros Serrano } \\
\text { Gámez }\end{array}$ & Serrano & 1972 & Metal & 77 & 240 \\
\hline $\begin{array}{c}\text { Grupo Luis } \\
\text { Caballero }\end{array}$ & Caballero & 1830 & $F \& B$ & 67 & 201 \\
\hline Grupo Joly & Joly & 1867 & Communication & 64 & 40 \\
\hline $\begin{array}{l}\text { Almacenes } \\
\text { Costasol }\end{array}$ & González & 1979 & Retailing & 56 & 100 \\
\hline \multicolumn{6}{|c|}{ GALICIA (13 FIRMS) } \\
\hline Banco Pastor & $\begin{array}{c}\text { Barrié de la } \\
\text { Maza-Arias }\end{array}$ & 1925 & Banking & $\begin{array}{c}124,603 \\
\text { (net profits) }\end{array}$ & 4,035 \\
\hline Pescanova & Fdez. Sousa & 1960 & $\mathrm{~F} \& \mathrm{~B}$ & 999 & 3,399 \\
\hline Calvo & Calvo & 1908 & $F \& B$ & 330 & 3,000 \\
\hline $\begin{array}{l}\text { Jealsa } \\
\text { Rianxeira }\end{array}$ & Alonso & 1958 & $F \& B$ & 314 & 3,060 \\
\hline ACTEMSA & Escurris & 1987 & $\mathrm{~F} \& \mathrm{~B}$ & 110 & 60 \\
\hline $\begin{array}{l}\text { Dielectro } \\
\text { Industrial } \\
\end{array}$ & Lostale & 1951 & Retailing & 108 & 375 \\
\hline $\begin{array}{r}\text { Maderas } \\
\text { Iglesias }\end{array}$ & Iglesias & 1985 & Construction & 105 & 580 \\
\hline Eduardo Vieira & Vieira & 1953 & $F \& B$ & 105 & 2,600 \\
\hline $\begin{array}{c}\text { Hijos de Rivera } \\
\text { (Cerveza } \\
\text { Estrella) } \\
\end{array}$ & Rivera & 1906 & $F \& B$ & 100 & 265 \\
\hline $\begin{array}{l}\text { FINSA } \\
\text { Financiera } \\
\text { Maderera } \\
\end{array}$ & García & 1931 & Construction & 94 & 254 \\
\hline Albo & Albo & 1869 & $F \& B$ & 73 & 387 \\
\hline Grupo Cuevas & Cuevas & 1978 & $F \& B$ & 72 & 398 \\
\hline $\begin{array}{l}\text { Freire } \\
\text { Hermanos }\end{array}$ & Freire & 1943 & Retailing & 72 & 83 \\
\hline
\end{tabular}


PALOMA FERNÁNDEZ PÉREZ/NÚRIA PUIG RAPOSO

\begin{tabular}{|c|c|c|c|c|c|}
\hline $\begin{array}{l}\text { Group } \\
\text { Name }\end{array}$ & Family & $\begin{array}{c}\text { Date of } \\
\text { foundation }\end{array}$ & Sector & $\begin{array}{c}\text { Turnover } \\
\text { (million euros) }\end{array}$ & Employees \\
\hline \multicolumn{6}{|c|}{ BALEARES (11 FIRMS) } \\
\hline $\begin{array}{l}\text { Banca March/ } \\
\text { Corporación } \\
\text { Financiera } \\
\text { Alba }\end{array}$ & March & 1926 & Banking & $\begin{array}{c}298,396 \\
\text { (net profits) }\end{array}$ & 1,377 \\
\hline Iberostar & Fluxá & 1930 & Tourism & 2,783 & 18,400 \\
\hline $\begin{array}{l}\text { Globalia } \\
\text { Corporación } \\
\text { (Viajes Halcón, } \\
\text { Air Europa) } \\
\end{array}$ & Hidalgo & 1971 & Tourism & 2,598 & 8,001 \\
\hline Sol Meliá & Escarrer & $1956 / 1987$ & Tourism & 1,165 & 11,357 \\
\hline Barceló & Barceló & $1931 / 1960$ & Tourism & 1,004 & 16,065 \\
\hline Riu & Riu & 1953 & Tourism & 900 & 16,000 \\
\hline Coflusa/Camper & Fluxá & 1981 & Footwear & 135 & 217 \\
\hline \begin{tabular}{l|} 
Vibrados y \\
Pretensados \\
Manacor \\
\end{tabular} & $\begin{array}{l}\text { Brunet + } \\
\text { Mascaró }\end{array}$ & 1968 & $\begin{array}{l}\text { Construction } \\
\text { (concrete) }\end{array}$ & 88 & 28 \\
\hline $\begin{array}{l}\text { Distribuidora } \\
\text { Rotger }\end{array}$ & Rotger & 1974 & Retailing & 87 & 436 \\
\hline $\begin{array}{l}\text { Viajes } \\
\text { Sidetours }\end{array}$ & Quetglas & 1975 & Tourism & 61 & 90 \\
\hline Hoteles Fiesta & Matutes & $1960 \mathrm{~s}$ & Tourism & 42 & 568 \\
\hline \multicolumn{6}{|c|}{ ARAGÓN (11 FIRMS) } \\
\hline $\begin{array}{l}\text { SA Minera } \\
\text { Catalana- } \\
\text { Aragonesa } \\
\text { SAMCA } \\
\end{array}$ & Luengo & 1919 & Mining & 751 & 5,250 \\
\hline $\begin{array}{l}\text { SA Industrias } \\
\text { Celulosa } \\
\text { Aragón } \\
\text { SAICA } \\
\end{array}$ & Balet & 1943 & Paper & 441 & 587 \\
\hline Álvarez Beltrán & Álvarez & 1979 & Logistics & 211 & 757 \\
\hline Pikolín & Solans & 1948 & Bed equipment & 182 & 1,393 \\
\hline $\begin{array}{l}\text { Transportes } \\
\text { Ochoa TOSA }\end{array}$ & Ochoa & $1930 \mathrm{~s}$ & Logistics & 141 & 1,117 \\
\hline Lecitrailer & Reciñera & 1990 & Logistics & 116 & 226 \\
\hline $\begin{array}{l}\text { Heraldo } \\
\text { de Aragón }\end{array}$ & Yarza & 1909 & Communication & 91 & 465 \\
\hline $\begin{array}{l}\text { Agreda } \\
\text { Automóvil }\end{array}$ & Calvo & 1927 & Motor & 82 & 5,260 \\
\hline $\begin{array}{c}\text { Transportes } \\
\text { Carreras }\end{array}$ & Carreras & $1930 s-1968$ & Logistics & 68 & 685 \\
\hline $\begin{array}{l}\text { Celulosa } \\
\text { Fabril CEFA }\end{array}$ & Blanchard & 1946 & Paper & 66 & 245 \\
\hline
\end{tabular}


BONSAIS IN A WILD FOREST? A HISTORICAL INTERPRETATION OF THE LONGEVITY...

\begin{tabular}{|c|c|c|c|c|c|}
\hline $\begin{array}{l}\text { Group } \\
\text { Name }\end{array}$ & Family & $\begin{array}{c}\text { Date of } \\
\text { foundation }\end{array}$ & Sector & $\begin{array}{c}\text { Turnover } \\
\text { (million euros) }\end{array}$ & Employees \\
\hline Lacasa & Lacasa & 1852 & $\mathrm{~F} \& \mathrm{~B}$ & 42 & 127 \\
\hline \multicolumn{6}{|c|}{ BASQUE COUNTRY (9 FIRMS) } \\
\hline Vidrala & Delclaux & 1965 & Glass & 297 & 1,114 \\
\hline $\begin{array}{r}\text { Conservas } \\
\text { Garavilla } \\
\end{array}$ & Garavilla & 1887 & $\mathrm{~F} \& \mathrm{~B}$ & 210 & 560 \\
\hline Cegasa & Celaya & 1934 & $\begin{array}{l}\text { Electrical } \\
\text { equipment }\end{array}$ & 200 & 1,000 \\
\hline $\begin{array}{l}\text { Corp. Patricio } \\
\text { Echevarría }\end{array}$ & Echeverría & 1908 & $\begin{array}{l}\text { Machine } \\
\text { Manufacturing }\end{array}$ & 187 & 1,887 \\
\hline Sener & Sendagorta & 1956 & Engineering & 151 & 918 \\
\hline Erhardt & Erhardt & 1882 & Logistics & 127 & 652 \\
\hline Minersa & Lipperheide & $1925 / 1942$ & Minerals & 125 & 167 \\
\hline $\begin{array}{l}\text { Marqués } \\
\text { de Riscal }\end{array}$ & $\begin{array}{c}\text { Hurtado de } \\
\text { Amézaga }\end{array}$ & 1858 & $\mathrm{~F} \& \mathrm{~B}$ & 48 & 180 \\
\hline $\begin{array}{l}\text { Ramón } \\
\text { Vizcaíno }\end{array}$ & Vizcaíno & 1932 & Freezing & 46 & 395 \\
\hline \multicolumn{6}{|c|}{ CASTILLA-LEÓN (7 FIRMS) } \\
\hline Antolín & Antolín & $1959 / 1985$ & Motor & 1,780 & 9,910 \\
\hline Leche Pascual & Pascual & 1969 & $\mathrm{~F} \& \mathrm{~B}$ & 992 & 4,300 \\
\hline Campofrío & Ballvé & 1952 & $\mathrm{~F} \& \mathrm{~B}$ & 911 & 2,500 \\
\hline Siro & González Serna & 1966 & F\&B & 136 & 945 \\
\hline Helios & Pérez & $1900 \mathrm{~s} / 1936$ & $\mathrm{~F} \& \mathrm{~B}$ & 99 & 210 \\
\hline Gullón & Gullón & 1892 & $\mathrm{~F} \& \mathrm{~B}$ & 92 & 350 \\
\hline Seda Solubles & Alonso Cruz & 1957 & F\&B & 67 & 283 \\
\hline \multicolumn{6}{|c|}{ CASTILLA-LA MANCHA (5 FIRMS) } \\
\hline García Baquerd & García Baquero & 1962 & $F \& B$ & 170 & 140 \\
\hline Félix Solís & Solís & $1950 \mathrm{~s}$ & $\mathrm{~F} \& \mathrm{~B}$ & 146 & 278 \\
\hline $\begin{array}{c}\text { Bodegas } \\
\text { Navarro } \\
\end{array}$ & Navarro López & 1904 & $\mathrm{~F} \& \mathrm{~B}$ & 139 & 35 \\
\hline Forlasa & $\begin{array}{l}\text { Ortega } \\
\text { Martínez }\end{array}$ & 1970 & $\mathrm{~F} \& \mathrm{~B}$ & 111 & 244 \\
\hline Delaviuda & López, Rojas & 1927 & $\mathrm{~F} \& \mathrm{~B}$ & 59 & 267 \\
\hline \multicolumn{6}{|c|}{ ASTURIAS (5 FIRMS) } \\
\hline $\begin{array}{l}\text { Industrias } \\
\text { Lácteas } \\
\text { Asturianas }\end{array}$ & Rodríguez & 1960 & $\mathrm{~F} \& \mathrm{~B}$ & 454 & 841 \\
\hline $\begin{array}{c}\text { Corporación } \\
\text { Masaveu }\end{array}$ & Masaveu & 1840 & Various & 391 & 5 \\
\hline Tudela Veguín & Masaveu & 1898 & $\begin{array}{l}\text { Construction } \\
\text { (concrete) }\end{array}$ & 356 & 877 \\
\hline Alsa-Enatcar & Cosmen & 1923 & Logistics & 318 & 3,100 \\
\hline
\end{tabular}


PALOMA FERNÁNDEZ PÉREZ/NÚRIA PUIG RAPOSO

\begin{tabular}{|c|c|c|c|c|c|}
\hline $\begin{array}{l}\text { Group } \\
\text { Name }\end{array}$ & Family & $\begin{array}{c}\text { Date of } \\
\text { foundation }\end{array}$ & Sector & $\begin{array}{c}\text { Turnover } \\
\text { (million euros) }\end{array}$ & Employees \\
\hline Martín Navarro & $\begin{array}{c}\text { Martín Navarro } \\
\text { and Ballester }\end{array}$ & 1946 & Retailing-F\&B & 146 & 644 \\
\hline \multicolumn{6}{|c|}{ RIOJA (4 FIRMS) } \\
\hline $\begin{array}{l}\text { Conservas } \\
\text { Cidacos }\end{array}$ & Baroja & 1950 & $\mathrm{~F} \& \mathrm{~B}$ & 92 & 197 \\
\hline Grupo Indal & Arias & 1963 & $\begin{array}{l}\text { Electrical } \\
\text { equipment }\end{array}$ & 83 & 950 \\
\hline Grupo Barpimo & Ros & 1959 & Chemicals & 65 & 500 \\
\hline Celorrio & Celorrio & 1950s & $\mathrm{F} \& \mathrm{~B}$ & 53 & 18 \\
\hline \multicolumn{6}{|c|}{ MURCIA (4 FIRMS) } \\
\hline El Pozo & Fuertes & 1936 & $\mathrm{~F} \& \mathrm{~B}$ & 460 & 2,855 \\
\hline García Carrión & García Carrión & $19^{\text {th }}$ century & $F \& B$ & 379 & 360 \\
\hline $\begin{array}{l}\text { AMC Grupo } \\
\text { Alimentación } \\
\text { Frescos } \\
\text { y Zumos } \\
\end{array}$ & Muñoz & 1950 & $\mathrm{~F} \& \mathrm{~B}$ & 288 & 999 \\
\hline García Aranda & García & 1941 & $\mathrm{~F} \& \mathrm{~B}$ & 78 & 170 \\
\hline \multicolumn{6}{|c|}{ EXTREMADURA (3 FIRMS) } \\
\hline Banca Pueyo & Pueyo & 1890 & Banking & $\begin{array}{c}4,671 \\
\text { (net profits) }\end{array}$ & 204 \\
\hline $\begin{array}{l}\text { Alfonso } \\
\text { Gallardo }\end{array}$ & Gallardo & $1960 \mathrm{~s}$ & Metal-mineral & 110,16 & 225 \\
\hline López Morenas & López & 1943 & $\mathrm{~F} \& \mathrm{~B}$ & 43,78 & 89 \\
\hline \multicolumn{6}{|c|}{ CANARIAS (2 FIRMS) } \\
\hline $\begin{array}{l}\text { José Sánchez } \\
\text { Peñate }\end{array}$ & Sánchez & 1963 & $\mathrm{~F} \& \mathrm{~B}$ & 76 & 430 \\
\hline $\begin{array}{c}\text { Grupo Kalise- } \\
\text { Menorquina }\end{array}$ & Suárez & 1940 & $\mathrm{~F} \& \mathrm{~B}$ & 235 & 1,407 \\
\hline \multicolumn{6}{|c|}{ CANTABRIA (1 FIRM) } \\
\hline \begin{tabular}{|l|} 
Banco de \\
Santander
\end{tabular} & Botín & 1857 & Banking & $\begin{array}{l}6,220.104 \\
\text { (net profits) }\end{array}$ & 129,196 \\
\hline \multicolumn{6}{|c|}{ NAVARRE (1 FIRM) } \\
\hline $\begin{array}{l}\text { Victorio } \\
\text { Luzuriaga }\end{array}$ & Luzuriaga & 1898 & Motor & 50 & 363 \\
\hline
\end{tabular}

Sources: Actualidad Económica, 2006, SABI, and corporate websites.

Notes:

1. The firms and groups of firms in this table fulfil three requirements: $a$ ) they were family-controlled firms in 2005 ; $b$ ) they were historic, counting on the involvement of a second generation; $c$ ) they had a turnover in excess of 40 million euros in 2005 .

2. $\mathrm{F} \& \mathrm{~B}=\mathrm{Food}$ and Beverages.

3. Visible members of the IEF (Instituto de la Empresa Familiar) are in bold.

4. Since 2005 Chupa Chups, Panrico, Uniland and Caprabo in Catalonia have sold out and lost their family status. The cases of Cortefiel and Grupo Indas in Madrid are similar. 
BONSAIS IN A WILD FOREST? A HISTORICAL INTERPRETATION OF THE LONGEVITY...

TABLE 2

FOUNDATION DATE OF THE 245 LARGEST HISTORICAL FAMILY FIRMS IN SPAIN, 2005

\begin{tabular}{|c|c|c|c|c|c|}
\hline Region & Before 1900 & $1900-1939$ & 1940-1975 & After 1975 & $\begin{array}{l}\text { Number of } \\
\text { firms and } \% \\
\text { of total }\end{array}$ \\
\hline Catalonia & 15 & 18 & 43 & 8 & $84(34,28 \%)$ \\
\hline Madrid & 5 & 5 & 18 & 7 & $35(14,28 \%)$ \\
\hline Valencia & 2 & 1 & 17 & 8 & $28(11,42 \%)$ \\
\hline Andalusia & 6 & 1 & 9 & 6 & $22(8,97 \%)$ \\
\hline Galicia & 1 & 4 & 5 & 3 & $13(5,30 \%)$ \\
\hline Aragón & 1 & 5 & 3 & 2 & $11(4,48 \%)$ \\
\hline Balearic Islands & 0 & 3 & 6 & 2 & $11(4,48 \%)$ \\
\hline Basque Country & 0 & 3 & 5 & 1 & $9(3,67 \%)$ \\
\hline Castilla-León & 1 & 1 & 5 & 0 & $7(2,85 \%)$ \\
\hline Castilla-La Mancha & 0 & 2 & 3 & 0 & $5(2,04 \%)$ \\
\hline Asturias & 2 & 1 & 2 & 0 & $5(2,04 \%)$ \\
\hline Murcia & 1 & 1 & 2 & 0 & $4(1,63 \%)$ \\
\hline Rioja & 0 & 0 & 4 & 0 & $4(1,63 \%)$ \\
\hline Extremadura & 1 & 0 & 2 & 0 & $3(1,22 \%)$ \\
\hline Canary Islands & 0 & 0 & 2 & 0 & $2(0,81 \%)$ \\
\hline Cantabria & 1 & 0 & 0 & 0 & $1(0,40 \%)$ \\
\hline Navarre & 1 & 0 & 0 & 0 & $1(0,40 \%)$ \\
\hline Total Spain & $37(15,10 \%)$ & $45(18,36 \%)$ & $126(51,42 \%)$ & $37(15,10 \%)$ & $245(100 \%)$ \\
\hline
\end{tabular}

TABLE 3

MAIN ACTIVITY OF THE 245 LARGEST HISTORICAL FAMILY FIRMS, SPAIN 2005

\begin{tabular}{|l|c|}
\hline \multicolumn{1}{|c|}{ Sector } & Number of firms and \% of total \\
\hline Food and Beverages & $72(29,38 \%)$ \\
\hline Construction & $35(14,28 \%)$ \\
\hline Retailing & $21(8,57 \%)$ \\
\hline Chemicals and Pharmaceuticals & $17(6,93 \%)$ \\
\hline Auxiliary industries & $17(6,93 \%)$ \\
\hline Tourism & $12(4,89 \%)$ \\
\hline Textiles and Footwear & $10(4,08 \%)$ \\
\hline Communication & $9(3,67 \%)$ \\
\hline Engineering & $6(2,44 \%)$ \\
\hline Other & $46(18,77 \%)$ \\
\hline Total & $245(100 \%)$ \\
\hline
\end{tabular}

Source: Same as Table 1

Other includes banking, legal services, insurance, gambling, real estate, paper, optics, leather, furniture, security, toys, bed equipment, and logistics. 
